\title{
Arsenic Concentration in the Surface Water of a Former Mining Area: The La Junta Creek, Baja California Sur, Mexico
}

\author{
Jobst Wurl ${ }^{1, *(\mathbb{D})}$, Miguel Imaz Lamadrid ${ }^{1}$, Lía Mendez-Rodriguez ${ }^{2}$ (i) and \\ Baudilio Acosta Vargas 2 \\ 1 Departamento Académico de Ciencias de la Tierra, Universidad Autónoma de Baja California Sur, \\ Carretera al sur Km 5.5, La Paz 23080, Mexico; mimaz_17@alu.uabcs.mx \\ 2 Centro de Investigaciones Biológicas del Noroeste S. C. (Cibnor) Mar Bermejo 195, Playa Palo de Santa Rita, \\ La Paz 23096, Mexico; lmendez04@cibnor.mx (L.M.-R.); b_acosta04@hotmail.com (B.A.V.) \\ * Correspondence: jwurl@uabcs.mx; Tel.: +52-612-123-8800 (ext. 4230)
}

Received: 31 December 2017; Accepted: 20 February 2018; Published: 2 March 2018

\begin{abstract}
The mining activity in the San Antonio-El Triunfo district, located in a mountainous region at $60 \mathrm{~km}$ southeast of La Paz, occured for more than 250 years and left behind severe contamination of soils and riverbed sediments which led to elevated concentrations of arsenic and other trace elements in the surface- and groundwater of the region. Although the main mining activity ended around 1911, contamination is still beeing distributed, especially from left behind tailings and mine waste piles. The contamination levels in the groundwater have been reported in several studies, but there is little information available on the surface water quality, and especially the temporal variation. In this study, we analyzed the surface water of the La Junta creek, in the southern part of the San Antonio-El Triunfo mining district. The working hypothesis was that by means of a spatial analysis of surface water and shallow groundwater, in combination with the temporal observation of the concentrations in runoff water, the effects of different sources of arsenic (natural geogene anomalies, due to historic mining activity, and hydrothermal related impact) in the La Junta creek can be recognized. This present study revealed that historic mining activity caused a mojor impact of arsenic but less contamination was observed than in the northern part of the district and elevated arsenic concentrations in stream water generally occurred during times of low streamflow.
\end{abstract}

Keywords: San Antonio-El Triunfo mining district 1; hydrothermal and disseminated gold deposit 2; Los Cabos block 3; arsenopyrite oxidation 4

\section{Introduction}

The level of arsenic in drinking water of rural areas in Baja California Sur is elevated; $16 \%$ of the drinking water, obtained from 440 groundwater and surface water samples in the rural areas of the state, was contaminated with arsenic (above $0.025 \mathrm{mg} / \mathrm{L}$, which is the Mexican regulation standard for drinking water) and $4 \%$ contained more than $0.1 \mathrm{mg} / \mathrm{L}$ arsenic (maximum $0.5 \mathrm{mg} / \mathrm{L}$ ) [1] . The highest values were obtained from two wells, located in the San Antonio-El Triunfo mining district. This mining district is divided into three watersheds: The northwestern El Triunfo area is situated in the El Carizal catchment and drains to the Pacific Ocean, meanwhile the northeastern San Antonio area is situated in the Los Planes watershed and drains to the Gulf of California [2]. The southern area of the mining district represents the smallest part and belongs to the Cañada Honda watershed, which also drains to the Pacific Ocean (Figure 1). 


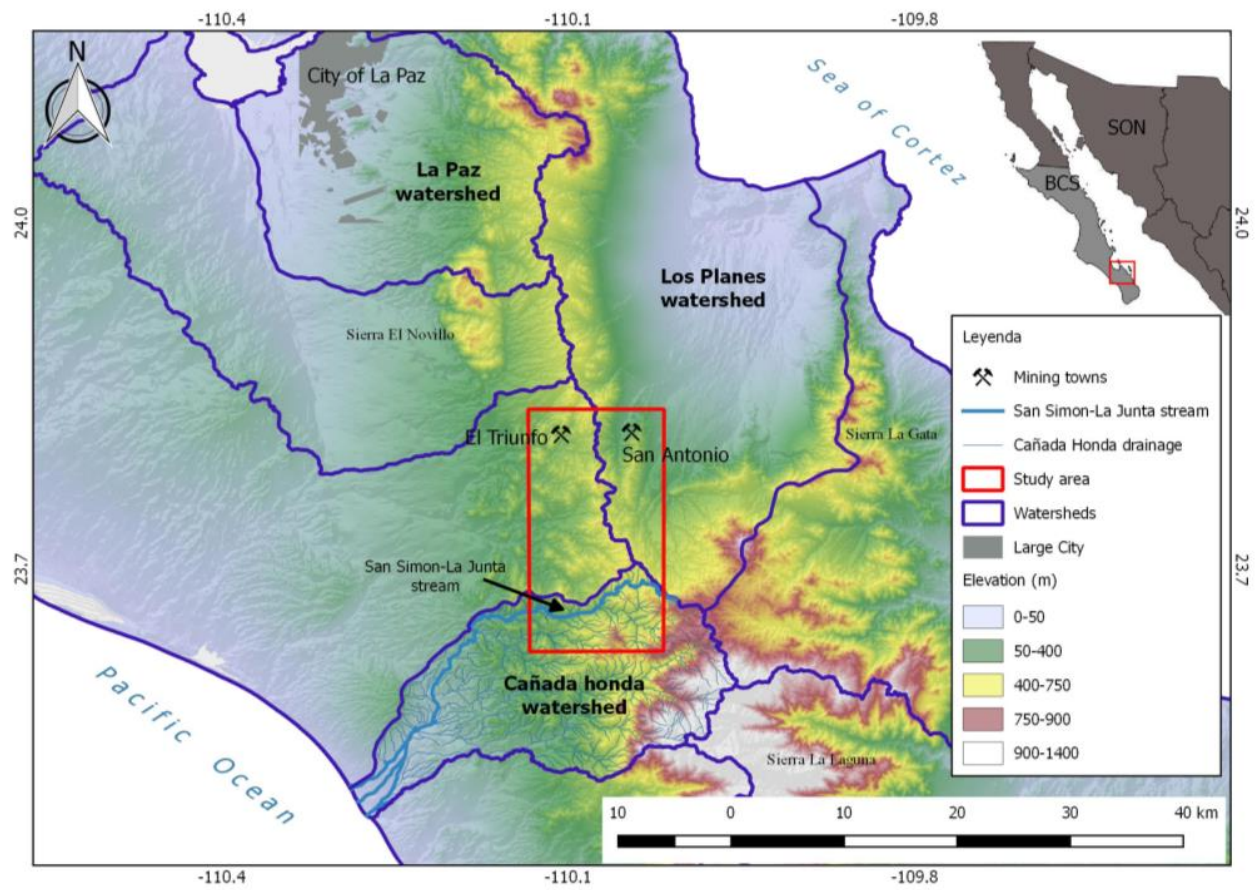

Figure 1. Location of the El Triunfo-San Antonio mining district (red line), with the creeks mensioned in the text: San Simon stream (dark blue), San Simon-La Junta stream (light blue) and La Muela (light green).

\subsection{The Cañada Honda Watershed}

This watershed, with the main drain (La Muela), occupies a total area of $441 \mathrm{~km}^{2}$ and the length of the perimeter is $99.1 \mathrm{~km}$. The angled dendritic drainage system reaches a maximum level of 6 (after the Strahler classification). The study area corresponds to the arroyo (creek) San Simón-La Junta with a length of $22 \mathrm{~km}$ and an area of $55 \mathrm{~km}^{2}$, which forms the southern part of the Triunfo-San Antonio mining district, representing the highest part of the Cañada Honda watershed (with a maximum of $1100 \mathrm{~m}$ above sea level [3]. After the Strahler classification, the drainage system of this sub-basin reaches a maximum level of 4 . The arroyo La Junta flows into the La Muela arroyo, which finally ends in the Pacific Ocean (Figure 1). Like for the rest of the state of Baja California Sur, the riverbeds are dry during most of the year and receive water only after heavy rainfall. The small creeks in the upper parts of the Sierra La Laguna Mountains often depend on temporal springs, which receive water from fractures in the metamorphic rocks during some weeks of the year. Therefore sampling of surface water is limited to a short time span after an important rain event.

\subsection{The La Junta Sub-Basin}

The arroyo La Junta forms part of the Sierra La Laguna Biosphere Reserve and is renowned for its high grade of biodiversity. Vanderplank et al., 2016 [4] documented the presence of 877 species, including 381 plants, 29 mammals, 77 birds, 366 insects, and 24 reptiles and amphibians. The majority of this diversity was found associated with the La Junta riparian system. Twenty-nine species, protected under Mexican law due to their inclusion on the endangered species list [5], were discovered as well as 107 species endemic to the Cape Region. The biodiversity, found in and around the arroyo La Junta and its tributaries, forms the base of a complex food-web with high levels of diversity and endemism; especially the multitude of life forms associated with aquatic habitats [4]. 


\subsection{Purpose of the Study}

The aim of our study was to define the composition of surface water and shallow groundwater and to detect possible pollution caused by historic gold mining in this area. Constituents of special interest are arsenic and related metals. The working hypotheses was that by means of a spatial analysis of surface water and shallow groundwater, in combination with the temporal observation of the concentrations in runoff water, the effects of different sources of arsenic (natural geogene anomalies, due to historic mining activity, and hydrothermal related impact) in the La Junta creek can be recognized.

\section{Materials and Methods}

\subsection{Climate}

The area is situated in a transition zone between the subtropical-tropical desert (typical of the Pacific coast of Baja California towards the north), and the more tropical climates to the south. The average annual temperature observed at the weather station San Antonio Sur (SMN no. 3049, located $15 \mathrm{~km}$ northeast of the project area), is $23.2{ }^{\circ} \mathrm{C}$ and the average day temperatures range from a winter low of $8.8^{\circ} \mathrm{C}$ to a summer high of $36.5^{\circ} \mathrm{C}$ [6]. The average annual rainfall in San Antonio Sur is 447 millimeters per year (period: 1951-2010) [6] but there is considerable variation, with a range of about 100 to $850 \mathrm{~mm}$ per year. Most of the rainfall occurs during the four months of July to October, due to the presence of tropical cyclones [7]. Storm intensity data for a return period of 10-year indicate a maximum precipitation of $17.5 \mathrm{~cm} / \mathrm{h}$ for the 10 -min event and $4.2 \mathrm{~cm} / \mathrm{h}$ for the 120 -min event at San Antonio Sur Station [8]. A secondary station (mainly in December and January) contributes between $5 \%$ and $10 \%$ of the average annual precipitation; during spring little or no precipitation occurs. The average potential evaporation greatly exceeds precipitation (2019.5 $\mathrm{mm}$ per year [6]).

\subsection{Soil Types and Vegetation}

The predominant soil types in the area are Regosols, mainly eutric Regosol, often associated with eutric Fluvisol and Lithosols. In some areas Litosols are associated with calcaric Regosols [3]). The flora and fauna of the arroyo La Junta have been described by Vanderplank et al., 2016 [4]). There is a co-occurrence of disparate vegetation types, such as tropical dry forest and pine forest, which intermix on the higher slopes; this habitat is distinguished by the following dominant plants: Bursera microphylla, Cyrtocarpa edulis, Jatropha cinerea, Lysiloma divaricata, L. candida, and Tecoma stans [4]. La Junta is surrounded by Tropical Dry Forest which covers the northwestern foothills of the Sierra La Laguna from 300-800 $\mathrm{m}[9]$.

\subsection{Geological Framework}

In the southern portion of Baja California Sur, the Sierra de la Laguna is the main high mountain range, with a maximum altitude of $2200 \mathrm{~m}$. The mountains are formed by a massif of Mesozoic crystalline basement, called the Los Cabos block [10], which is cut off to the east by the San José del Cabo fault, with a topographic escarpment in excess of $1000 \mathrm{~m}$, which forms the eastern limit of this block [11]. This crystalline complex comprises intermediate to silicic Cretaceous igneous rocks that intruded and metamorphosed early Mesozoic clastic and calcareous sedimentary rocks [12,13]. CAM, (2007) [14] describes the crystalline complex intrusive rocks, such as hornblende diorites, granites, granodiorites, tonalites and some gabbros, which are all intruded by andesitic and quartzomonzonitic dikes. Three different types of ore deposits are known in the area: epithermal veins containing high concentrations of sulfide associated with gold and silver, fault-related disseminated gold deposits in igneous rocks, and one disseminated gold deposit in metamorphic rock [15]. 


\subsection{Historical Mining Activity}

The first gold and silver mines were opened in the San Antonio-El Triunfo mining district in the eighteenth century but the major mining activity occured between 1878 and 1911 and ended in 1940 [16]. The metallurgical techniques applied for the extraction of gold from low grade ore included leaching with cyanide and recovery of gold by mercury amalgamation $[17,18]$. The main processing plants were located in the two villages of San Antonio and El Triunfo, which received the ore from the surrounding mines and had up to 7000 inhabitants at their peak at the end of the 19th century. When the mines were finally abandoned, thousands of tons of waste were left behind [16]. Due to the low efficiency ( $25 \%$ to $40 \%$ ) of the applied processing techniques, a reprocessing of the tales occured in the 1980s and by 1983 another 3.6 tons of gold, 700 tons of silver and 2500 tons of lead were produced [19]. Many historic mines are documented within the San Antonio-El Triunfo mining district; 13 of them are located within the study area (see Table 1 and Figure 2, after SGM, 2000 [20], modified).

Table 1. Characteristics of 13 historic gold mines in the study area (documented in [20]).

\begin{tabular}{|c|c|c|c|c|c|}
\hline No. & $\begin{array}{l}\text { Name of the } \\
\text { Gold Mine }\end{array}$ & Rock Type & $\begin{array}{l}\text { Type of Ore } \\
\text { Deposite }\end{array}$ & $\begin{array}{c}\text { Mineralization } \\
\text { Type }\end{array}$ & $\begin{array}{c}\text { Metal } \\
\text { Produced }\end{array}$ \\
\hline 1 & El Saucito & $\begin{array}{l}\text { Granite with diorite } \\
\text { and granodiorite }\end{array}$ & $\begin{array}{l}\text { Hydrothermal } \\
\text { veins }\end{array}$ & Sulfurous & $\mathrm{Au}, \mathrm{Ag}$ \\
\hline 2 & $\begin{array}{l}\text { Veta Arbol de } \\
\text { Oro }\end{array}$ & Granodiorite & $\begin{array}{l}\text { Hydrothermal } \\
\text { veins }\end{array}$ & Sulfurous & $\mathrm{Au}$ \\
\hline 3 & $\begin{array}{l}\text { Bajo Veta } \\
\text { Grande }\end{array}$ & Granodiorite & $\begin{array}{l}\text { Hydrothermal } \\
\text { veins }\end{array}$ & Sulfurous & $\mathrm{Au}, \mathrm{Ag}$ \\
\hline 4 & Veta Grande & Granodiorite & $\begin{array}{l}\text { Hydrothermal } \\
\text { veins }\end{array}$ & Sulfurous & $\mathrm{Au}, \mathrm{Ag}$ \\
\hline 5 & El Veladero & Granodiorite & $\begin{array}{l}\text { Hydrothermal } \\
\text { veins }\end{array}$ & Sulfurous & $\mathrm{Au}$ \\
\hline 6 & Veta de Otto & $\begin{array}{l}\text { Granite with diorite } \\
\text { and granodiorite }\end{array}$ & $\begin{array}{l}\text { Hydrothermal } \\
\text { veins }\end{array}$ & Sulfurous & $\mathrm{Au}$ \\
\hline 7 & Mr. Conn & $\begin{array}{l}\text { Granite with diorite } \\
\text { and granodiorite }\end{array}$ & $\begin{array}{l}\text { Hydrothermal } \\
\text { veins }\end{array}$ & Sulfurous & $\mathrm{Au}, \mathrm{Ag}$ \\
\hline 8 & $\begin{array}{l}\text { Paredones } \\
\text { Amarillos }\end{array}$ & $\begin{array}{l}\text { Granite with diorite } \\
\text { and granodiorite }\end{array}$ & $\begin{array}{c}\text { Hydrothermal, } \\
\text { disseminated } \\
\text { gold deposit }\end{array}$ & Sulfurous & $\mathrm{Au}$ \\
\hline 9 & Siempre Viva & $\begin{array}{l}\text { Granodiorite and } \\
\text { tonalite }\end{array}$ & $\begin{array}{l}\text { Hydrothermal } \\
\text { veins }\end{array}$ & Sulfurous & $\mathrm{Au}$ \\
\hline 10 & $\begin{array}{l}\text { Yerba de } \\
\text { Manzo }\end{array}$ & $\begin{array}{l}\text { Granodiorite and } \\
\text { tonalite }\end{array}$ & $\begin{array}{l}\text { Hydrothermal } \\
\text { veins }\end{array}$ & Sulfurous & $\mathrm{Au}, \mathrm{Ag}, \mathrm{Pb}$ \\
\hline 11 & La Zorra & $\begin{array}{l}\text { Granodiorite and } \\
\text { tonalite }\end{array}$ & $\begin{array}{l}\text { Hydrothermal } \\
\text { veins }\end{array}$ & Sulfurous & $\mathrm{Au}, \mathrm{Ag}$ \\
\hline 12 & La Encantada & $\begin{array}{l}\text { Granite with diorite } \\
\text { and granodiorite }\end{array}$ & $\begin{array}{l}\text { Hydrothermal } \\
\text { veins }\end{array}$ & Sulfurous & $\mathrm{Au}, \mathrm{Ag}, \mathrm{Pb}$ \\
\hline 13 & Adonde & $\begin{array}{c}\text { Granodiorite and } \\
\text { tonalite }\end{array}$ & $\begin{array}{l}\text { Hydrothermal } \\
\text { veins }\end{array}$ & Sulfurous & $\mathrm{Au}, \mathrm{Ag}, \mathrm{Pb}$ \\
\hline
\end{tabular}

\subsection{Contamination with Arsenic and Byproducts in the Mining District}

In previous studies of the mining district, elevated arsenic concentrations (up to $1.29 \mathrm{mg} / \mathrm{L}$ ) in groundwater had been reported [15,17]. Carrillo and Drever (1998) [19] concluded that significant arsenic contamination in groundwater is derived mainly from mine waste piles. Arsenolite $\left(\mathrm{As}_{2} \mathrm{O}_{3}\right)$ was historically produced as a byproduct of gold and silver extraction in Southernmost Baja California 
Peninsula. There are in the San Antonio-El Triunfo area more than 800,000 tons of mine waste material with an average content of $4 \%$ arsenic oxide. The chemical reaction to produce arsenic trioxide (arsenolite) was the oxidation of arsenopyrite (AsFeS) with gold (ore) to produce iron oxide $\left(\mathrm{Fe}_{2} \mathrm{O}_{3}\right)$ with gold and releasing $\mathrm{SO}_{2}$ and $\mathrm{As}_{2} \mathrm{O}_{3}$ fumes [15,17]. During and after mining activity the resulting ashes and wastes, which contain several by-products, were spread over an area of approximately $350-400 \mathrm{~km}^{2}$ via transport by wind and runoff [17]. The concentrations for $\mathrm{Pb}, \mathrm{Cd}$ and especially As in mining and smelting wastes of El Triunfo-San Antonio exceed the effects range median (ERM) of toxicity, defined by the EPA [16,21-23]. Due to the erosion of mine waste piles after storm events, the contamination was washed into the riverbed sediments and was transported to the lower parts of the watersheds, where it finally reached the Pacific coast to the west (watershed El Carrizal and Cañada Honda; [22] and the Gulf of California to the east (watershed Los Planes) [21,24].

\subsection{Contamination in the Cañada Honda Watershed}

The El Triunfo-San Antonio mining district occures across three watersheds: El Carizal and Los Planes and Cañada Honda, in the southern part. In Cañada Honda the concentration of arsenic (dissolved) exceeded the values established by the World Health Organization of $0.01 \mathrm{mg} / \mathrm{L}$ [25]) in $41 \%$ of the monitored sites; the maximum concentration, found in one observation well was $0.45 \mathrm{mg} / \mathrm{L}$ arsenic [26]. In surface sediments from river banks of the Canada Honda watershed, Sánchez Martínez et al. (2017) [22] reported enrichment factors of 5.3 for arsenic, 2.2 for copper and 1.6 for zinc with respect to average concentration of the continental crust reported by Wedepol (1995) [27]. Groundwater with a hydrothermal component was described at four sites in the central part of the La Junta arroyo (Figure 2). The water type is $\mathrm{Na}-\mathrm{Cl}$ but only low total mineralization $(325-393 \mu \mathrm{S} / \mathrm{cm})$ is observed with an alkaline $\mathrm{pH}$ between 9.3 and 9.6. The concentration of fluoride (1.79-3.25 mg/L) and boron (0.83-9.54 mg/L) are elevated meanwhile $\mathrm{Mg}$ and Ca concentrations are low (under $0.2 \mathrm{mg} / \mathrm{L}$ and $5 \mathrm{mg} / \mathrm{L}$ ) respectively [26]. Because the arsenic concentration in these samples was less than $0.008 \mathrm{mg} / \mathrm{L}$, it was concluded that no significant impact of arsenic from hydrothermal fluids was found in the study area.

A continuous monthly monitoring at three stations in the arroyo La Junta, see Figure 2) started in May 2010 and ended in January 2011. After several rainfall events in August and September, we could obtain water samples from 16 additional sites (6 from La Junta creek and its tributaries and 10 temporal springs and norias (hand-dug shallow wells)) in the study area.

The preservation methods, analytical protocols, and QA/QC controls were conducted according to standard methods for surface water analyses [28]. The $\mathrm{pH}$, redox potential (in Eh mode), dissolved oxygen, electrical conductivity, and temperature were determined on site with an Orion 5 star Benchtop Meter; acidity and alkalinity were measured in the field by titration with $0.05 \mathrm{~N} \mathrm{HCl}$ and $\mathrm{NaOH}$ solutions. The samples for cations, total concentration of trace metals and boron analysis were acidified with concentrated trace-metal grade $\mathrm{HNO}_{3}$ (to reach $\mathrm{pH}<2$ ). A second sample volume for dissolved trace metals was filtered through cellulose filters $(0.45 \mu \mathrm{m}$ of pore diameter $)$ and then acidified in the same way. A third sample for $\mathrm{CN}^{-}$analysis was treated with concentrated $\mathrm{NaOH}$ (to reach $\mathrm{pH}$ $>10$ ). A fourth sample volume for the analysis of anions, $\mathrm{pH}$, and electrical conductivity was stored at $4{ }^{\circ} \mathrm{C}$ elsius in order to minimize bacterial activity. The collected samples (all in HDPE bottles) were stored in ice boxes and sent to two laboratories in Mexico (Asesoría y Servicios Analiticos in La Paz and ALS Indequim in Monterrey) which are certified for all analyzed parameters; the parameters and applied methods are enlisted in Table 2. Analytical data were verified with standards, blank measurements, duplicate samples, and spikes in the field and in the laboratories. 


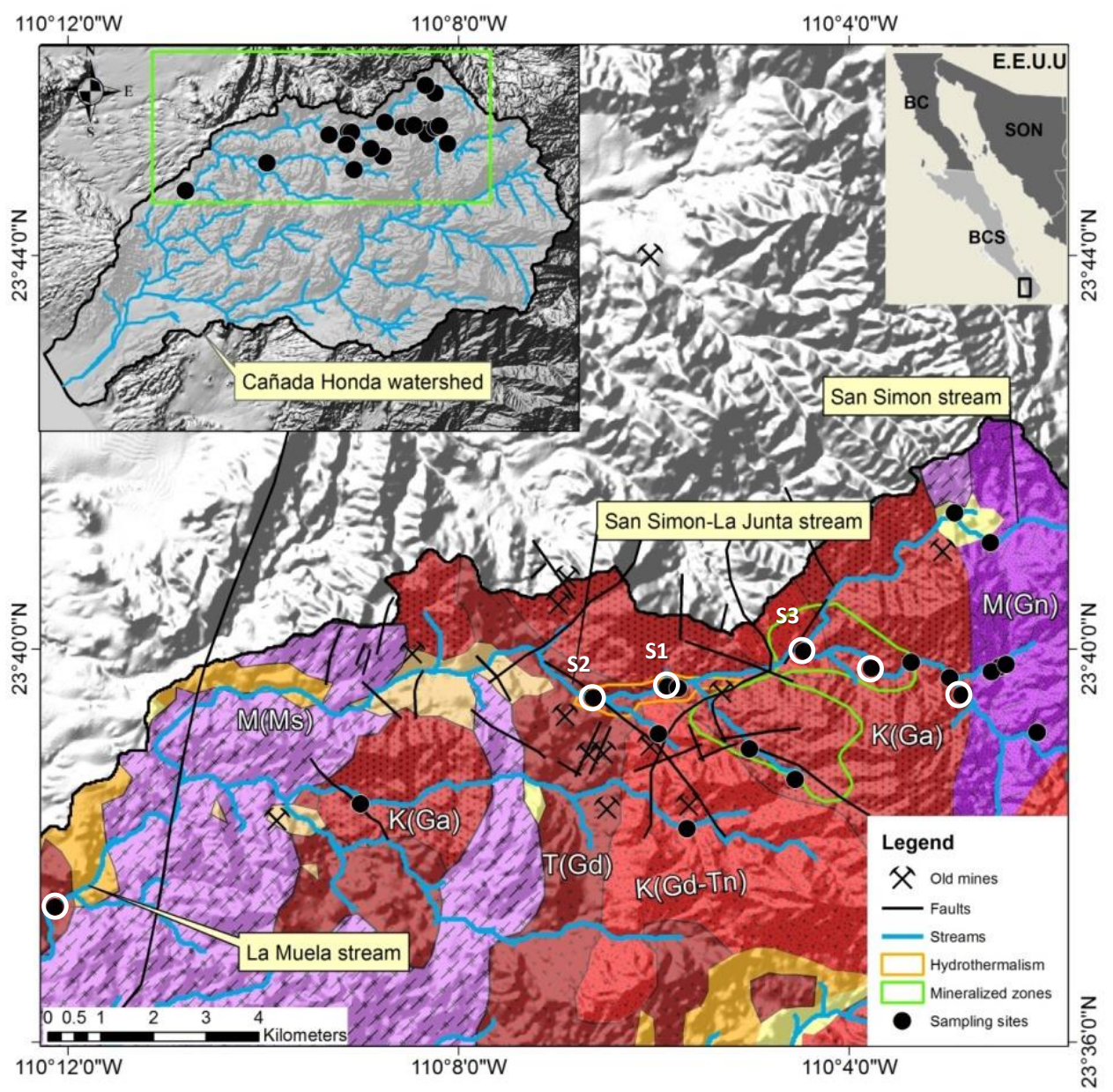

Figure 2. Geological map of the study area with the 19 stations where samples were taken in October 2010 (black dots); six stations correspond to surface water in the main arroyo (white circles), of which three (S1 to S3) were continuously sampled during the nine month sampling period. $(\mathrm{M}(\mathrm{Gn})$ $=$ Gneiss; $\mathrm{K}(\mathrm{Ga})=$ Gabbro; $\mathrm{M}(\mathrm{Ms})=$ Metasedimentary rock; $\mathrm{T}(\mathrm{Gd})$ = Granodiorites; $\mathrm{K}(\mathrm{Gd}-\mathrm{Tn})=$ Granodiorites - Tonalites).

Table 2. The applied methods for 35 analyzed parameters.

\begin{tabular}{|c|c|c|}
\hline Parameter & Methods & Reference \\
\hline The $\mathrm{pH}$ value & NMX-AA-008-SCFI-2000 & [29] \\
\hline Electrolytic conductivity & NMX-AA-093-SCFI-2000 & {$[30]$} \\
\hline Total alkalinity & NMX-AA-036-SCFI-2001 & [31] \\
\hline Chlorides & NMX-AA-073-SCFI-2001 & [32] \\
\hline Fluorides & NMXAA-077-SCFI-2001 & [33] \\
\hline Sulfates & NMX-AA-074-1981 & [34] \\
\hline $\begin{array}{l}\mathrm{Ca}, \mathrm{Mg}, \mathrm{Na}, \mathrm{Sr}, \mathrm{K}, \mathrm{Fe}, \mathrm{Ag}, \mathrm{Al}, \mathrm{As} \\
\mathrm{Ba}, \mathrm{Cd}, \mathrm{Co}, \mathrm{Cr}, \mathrm{Cu}, \mathrm{Li}, \mathrm{Mn}, \mathrm{Mo}, \mathrm{Ni} \\
\quad \mathrm{Pb}, \mathrm{Sb}, \mathrm{Zn}, \mathrm{Be}, \mathrm{Se}, \mathrm{Sn}, \mathrm{Bi}, \mathrm{Tl}\end{array}$ & \multicolumn{2}{|c|}{$\begin{array}{l}\text { ICP-MS according to USEPA Method 6020A [35]. The samples were } \\
\text { measured twice, with a filtrated sample and without filtration so that } \\
\text { dissolved concentration and total concentration were obtained. }\end{array}$} \\
\hline Mercury & \multicolumn{2}{|c|}{$\begin{array}{l}\text { Cold vapor atomic absorption spectroscopy, according to the Mexican } \\
\text { Norm NMX-AA-051-SCFI-2001 [36]. }\end{array}$} \\
\hline Cyanide and boron & \multicolumn{2}{|c|}{$\begin{array}{c}\text { Spectrophotometric techniques according to the Mexican Norms } \\
\text { NMX-AA-063-SCFI-2001 [37] and NMX-AA-058-SCFI-2001 at } 540 \mathrm{~nm} \\
\text { and } 578 \mathrm{~nm} \text { [38] }\end{array}$} \\
\hline
\end{tabular}




\subsection{Analysis Revision}

The quality of the analyses was revised, applying the rules established by DVWK [39], which in addition to the well-established data checks, define the rules that allow classifying analyzed parameters as conspicuous with respect to redox conditions. The levels of specific parameters in surface water were compared to the contamination levels found in mine waste piles [40], sediments [21,24], and ashes [16], and the chemical and mineralogical characterization of the different materials from the San Antonio-El Triunfo mining area [41]. In a Eh-pH stability diagram with comparable conditions, taken from Takeno (2005) [42], the dominant arsenic aqueous species were identified.

\subsection{Statistical Analysis}

We applied the Pearson's Product-Moment correlation analysis, which measures the strength of a linear dependence between two variables in order to identify possible associations among different variables. The data were tested on normality distribution (Kolmogorov-Smirnov test) in order to fulfill the requierments of the follwing analysis. The hierarchical cluster analysis permitted identifying similarity degrees among sampling stations and among spatial metal distributions. Ward's method was used in combination with the squared Euclidean Distance. Finally, to accomplish the cluster analysis requirements, a normality test (Kolmogorov-Smirnov) was applied. The statistical analysis was conducted, using SPSS 17.0 software (SPSS Inc., Chicago, IL, USA).

\section{Results}

The abundant water flow in October 2010 allowed taking samples at 19 sites (Figure 2), which included the stations S1, S2 and S3 and additional sites in the La Junta Arroyo and its tributariesand ten temporal springs and norias (hand-dug shallow wells). All analyses were considered reliable, applying the rules established by DVWK [39]. The results of 19 samples taken in October, (total and dissolved element concentrations including the charge balance error), are documented in the Table S1: Stations and the Table S2: Temporal Variations (May 2010-January 2011).

The water samples correspond to fresh water with concentrations of total dissolved solids, less than $1000 \mathrm{mg} / \mathrm{L}$. Total dissolved solids and electrical conductivity of the surface water are lower in the upper part of the arroyo La Junta $(670-850 \mu \mathrm{S} / \mathrm{cm})$ and $(850-1275 \mu \mathrm{S} / \mathrm{cm})$ in the center of the La Junta arroyo, an area where seven sites of historic mines are documented (Figure 3). The mineralization remains elevated when reaching the La Muela arroyo. The parameters $\mathrm{pH}, \mathrm{Mn}, \mathrm{HCO}_{3}, \mathrm{SO}_{4}$ and $\mathrm{Cl}$ follow this general tendency of an increase towards the La Muela creek meanwhile $\mathrm{Zn}$, Mo and the chemical demand of oxygen decrease.

There is an increase of the arsenic concentration from the upper part of the La Junta creek, observed in shallow groundwater (springs and norias) to the center of the arroyo La Junta with seven historic mines (Figure 4). At nine stations the concentration was measured above $0.01 \mathrm{mg} / \mathrm{L}$, which is the maximum value for drinking water, defined by WHO [25] and at three sites more than $0.025 \mathrm{mg} / \mathrm{L}$ arsenic was observed, exceeding the maximum value for drinking water under the Mexican regulation [43]. 


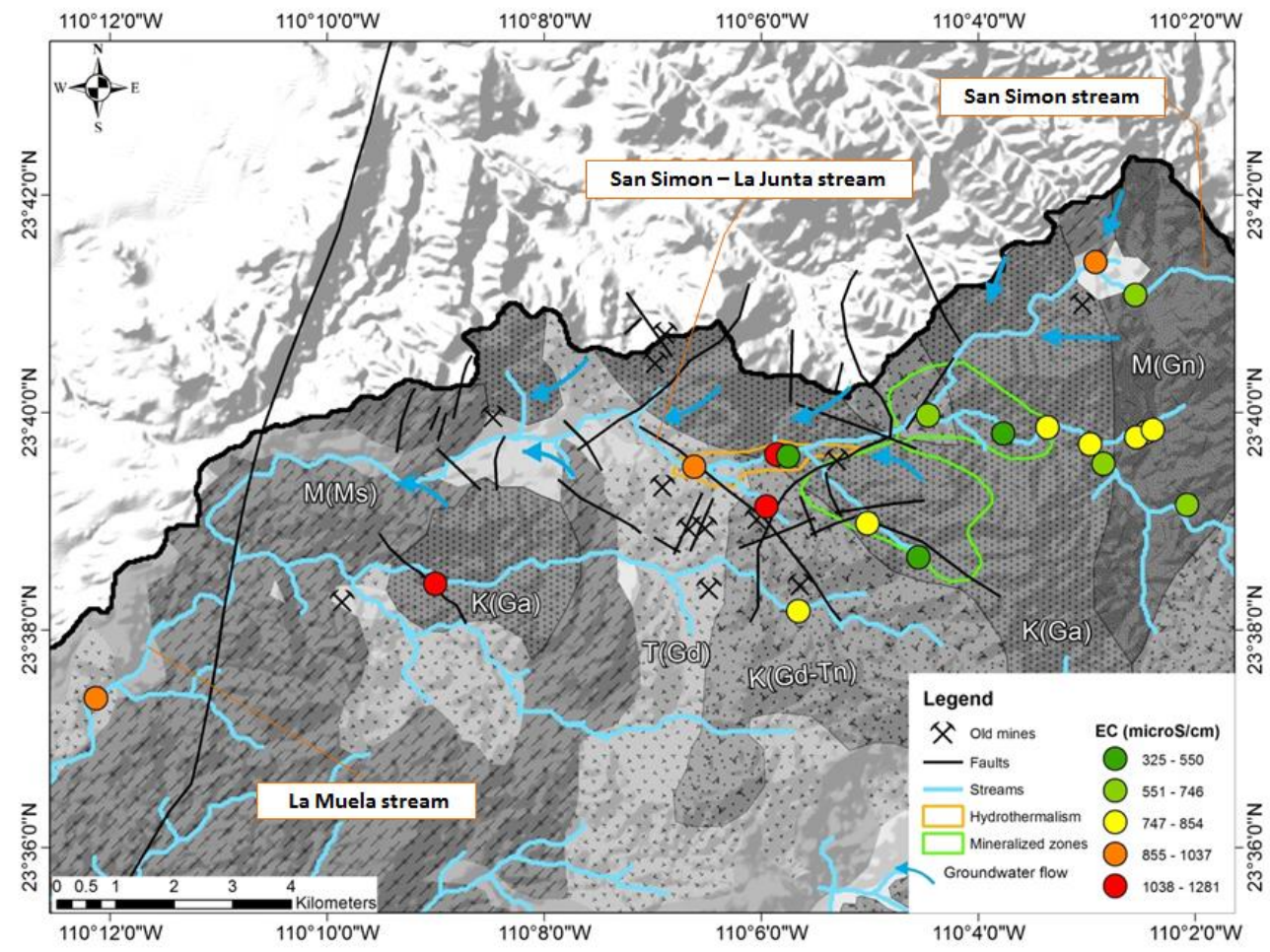

Figure 3. The electrical conductivity measured at 19 sites in the month of October. Blue arrows indicate areas with recognized influx of groundwater into the arroyo (creek) (see Wurl et al. 2014 [26]). Three areas with geochemical anomalies can be distinguished: the mineralized zone (gold, silver, and byproducts like arsenic), the area of hydrothermal manifestations, and the locations of historic mines.

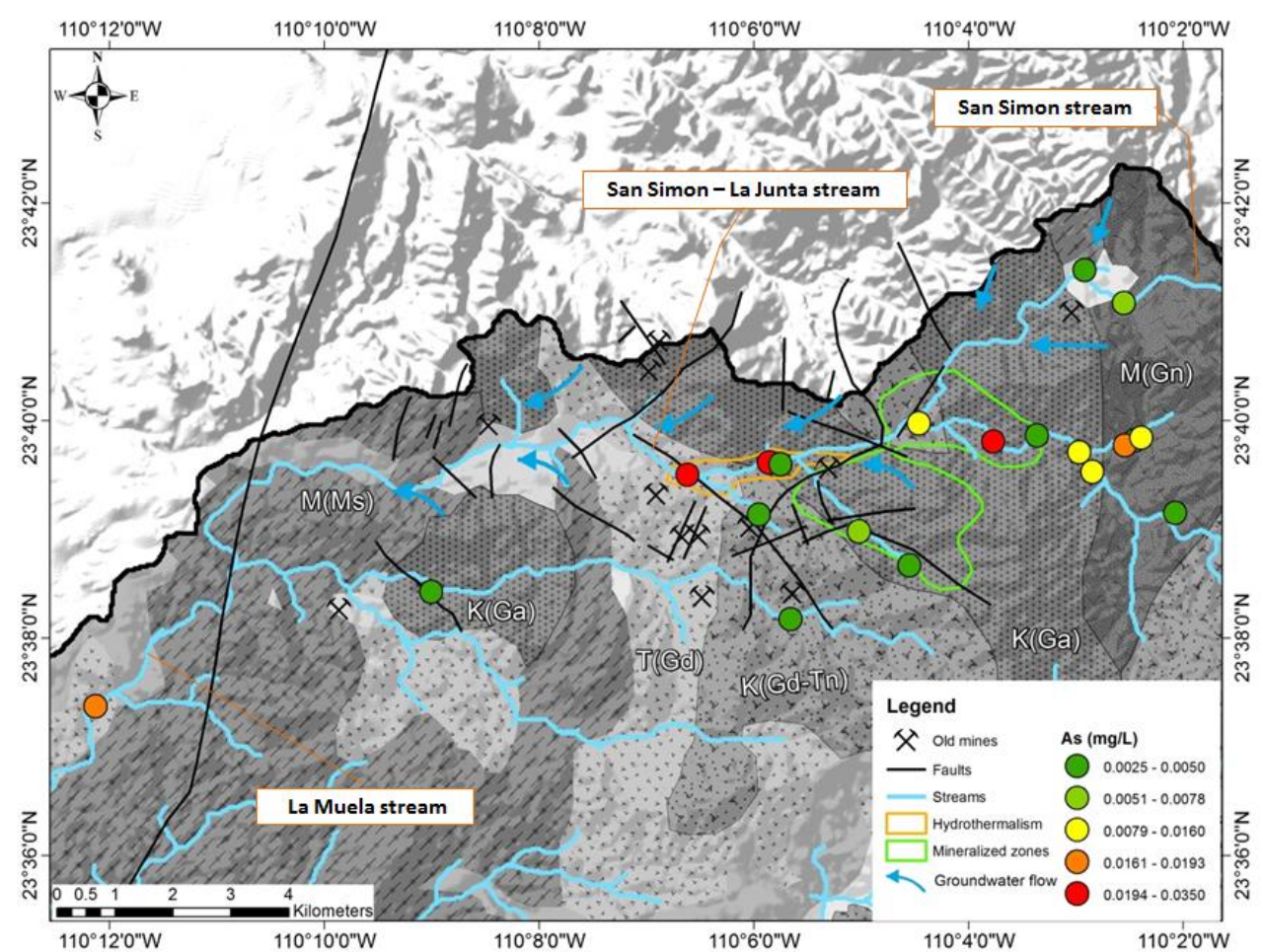

Figure 4. Arsenic concentrations in surface water observed at 19 locations in the month of October. Blue arrows indicate areas with recognized influx of groundwater into the arroyo (creek) (see Wurl et al. 2014 [26]). 
The Eh-pH conditions indicate that in the study area with oxidative environments, the dominant arsenic aqueous species is $\mathrm{HAsO}_{4}{ }^{2-}(\mathrm{As}(\mathrm{V}))$; only one sample corresponds to a more reduced environment where the aqueous species of $\mathrm{As}$ (III) are predominant, mainly $\mathrm{HAsO}_{2}$ (aq.) (Figure 5). Arsenic may be removed by sulfate reduction due to the incorporation into iron sulfides forming arsenopyrite (FeAsS). Adequate conditions may be found in hydrothermal systems where the temperature is typically above $100{ }^{\circ} \mathrm{C}$. Wurl et al. (2014) [26] found that the $\mathrm{pH}$ and redox conditions $(\mathrm{pH}>9.3$; Eh between -200 and $-300 \mathrm{mV}$, Figure 5) and the estimated equilibrium temperature (about $100{ }^{\circ} \mathrm{C}$ ) in the hydrothermal groundwater are suitable for arsenic precipitation.

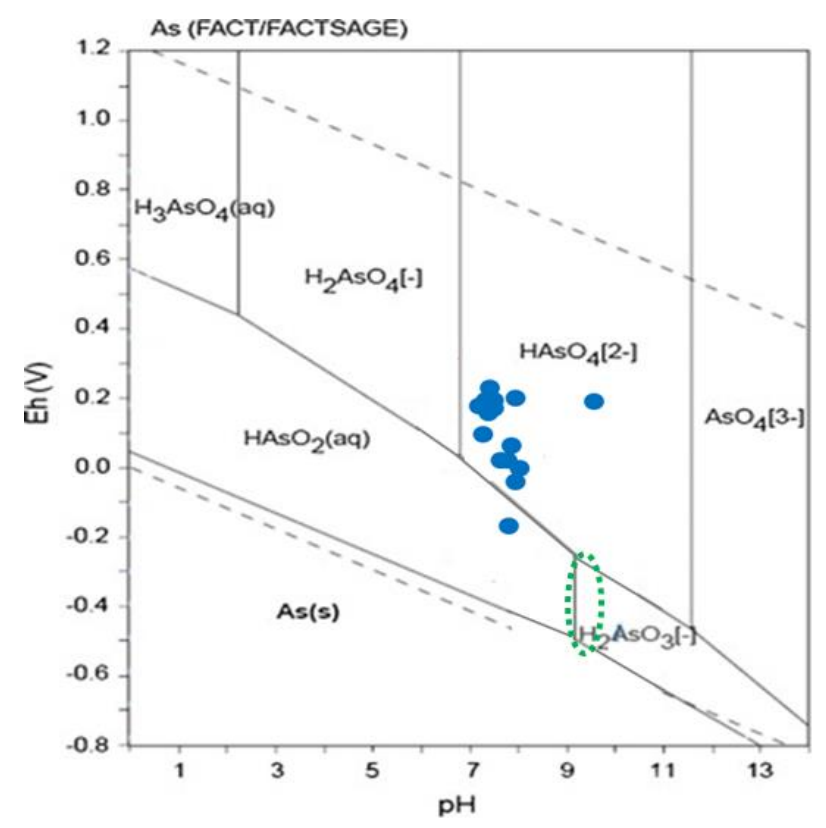

Figure 5. Position of surface water samples in an $\mathrm{Eh} / \mathrm{pH}$ diagram of the system $\mathrm{As}-\mathrm{O}-\mathrm{H}\left(\mathrm{As}_{\text {total }}=\right.$ $1 \mathrm{nM}, 298.15 \mathrm{~K}, 105 \mathrm{~Pa}$ ) from Takeno (2005) calculated with the program FACTSAGE [44]. The position of the green circle indicates the Eh- $\mathrm{pH}$ conditions in the thermal groundwater [26].

With respect to cyanide and the trace elements mercury, beryllium, selenium, silver, cadmium, tin, antimony, thallium, and bismuth, no concentrations above the limit of quantification of the corresponding method were detected. For the trace elements barium, lead, copper, total chromium and zinc, the concentrations of most samples were under the limit of quantification only in some cases concentrations were higher, but always below the maximum permissible limit according to WHO 2011 [25].

The impact of hydrothermal water is recognized through the elevated concentration of boron in the surface water (maximum $1.1 \mathrm{mg} / \mathrm{L}$, average 0.35 , standard deviation 0.28 ). The maximum was observed in the station located after the zone where hydrothermal wells are reknown [26], but the impact is more diffuse and not limited to this zone (Figure 6). 


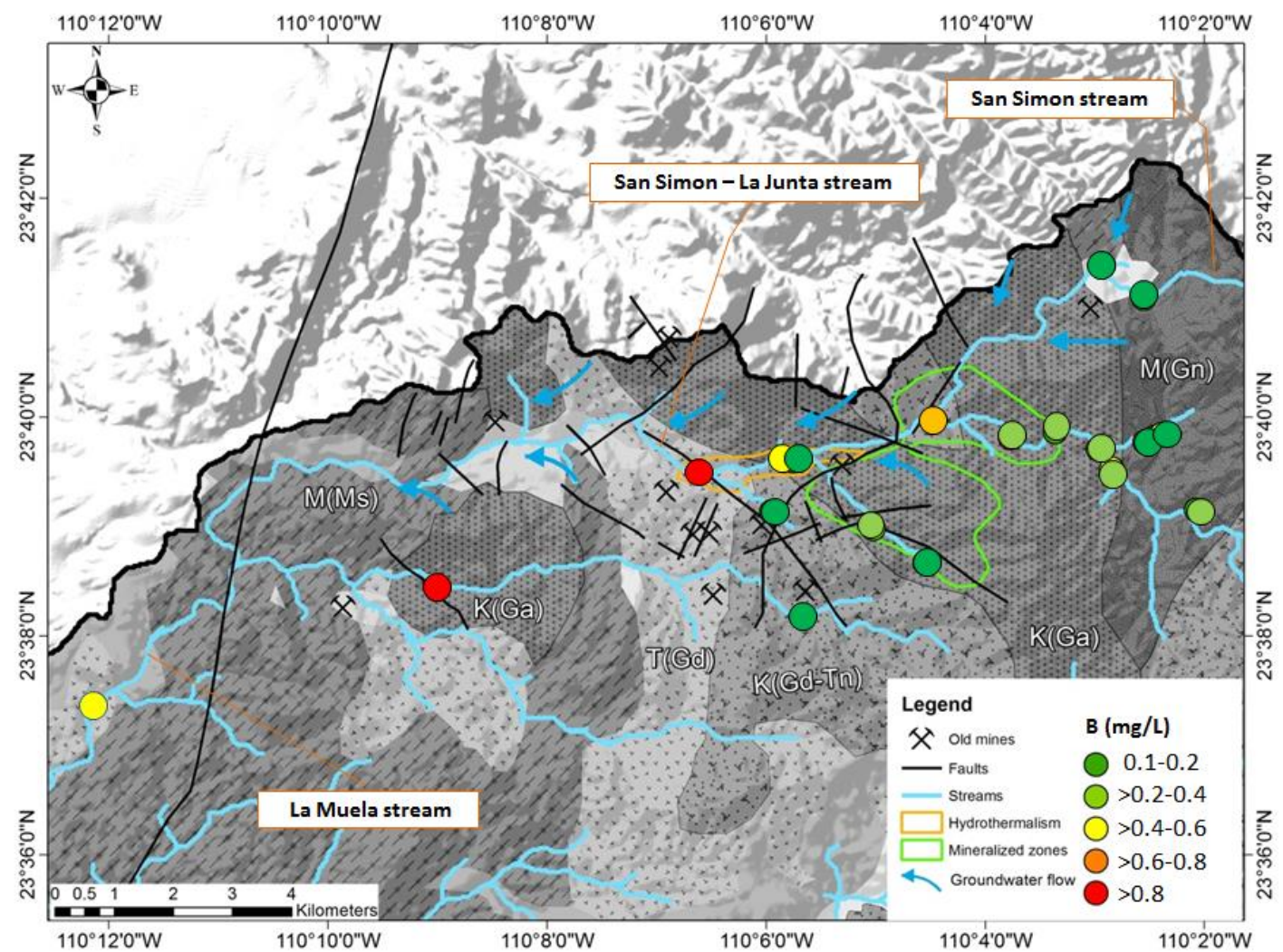

Figure 6. Concentrations of boron in the surface water observed at 19 locations in the month of October. Blue arrows indicate areas with recognized influx of groundwater into the arroyo (creek) (see Wurl et al. 2014 [26]).

\subsection{Statistical Analysis}

The calculation of the Pearson Correlation Coefficient (r) between the analyzed trace elements revealed no significant correlations (at a significance level $(p)<0.01$ ) among arsenic and any other parameter. In a cluster analysis the following 12 physico-chemical parameters were used: $\mathrm{Ca}, \mathrm{Mg}^{*}, \mathrm{Na}$, $\mathrm{Cl}^{*}, \mathrm{SO}_{4}^{*}, \mathrm{HCO}_{3}, \mathrm{~F}, \mathrm{~B}, \mathrm{As}^{*}, \mathrm{Mo}^{*}, \mathrm{EC}$ (electrolytic conductivity), and $\mathrm{pH}\left({ }^{*}\right.$ variable was transformed to $\log 10$ concentration values). Because the variables have different measurement levels, values are standardized to $\mathrm{z}$ scores, with a mean of 0 and a standard deviation of 1 . The cluster analysis was performed in Q-mode in order to define sample similarity, and in R-mode to define information similarity from different variables. In the resulting dendrogram in Q-mode, five different clusters could be distinguished at a fusion value of six (Figure 7). 


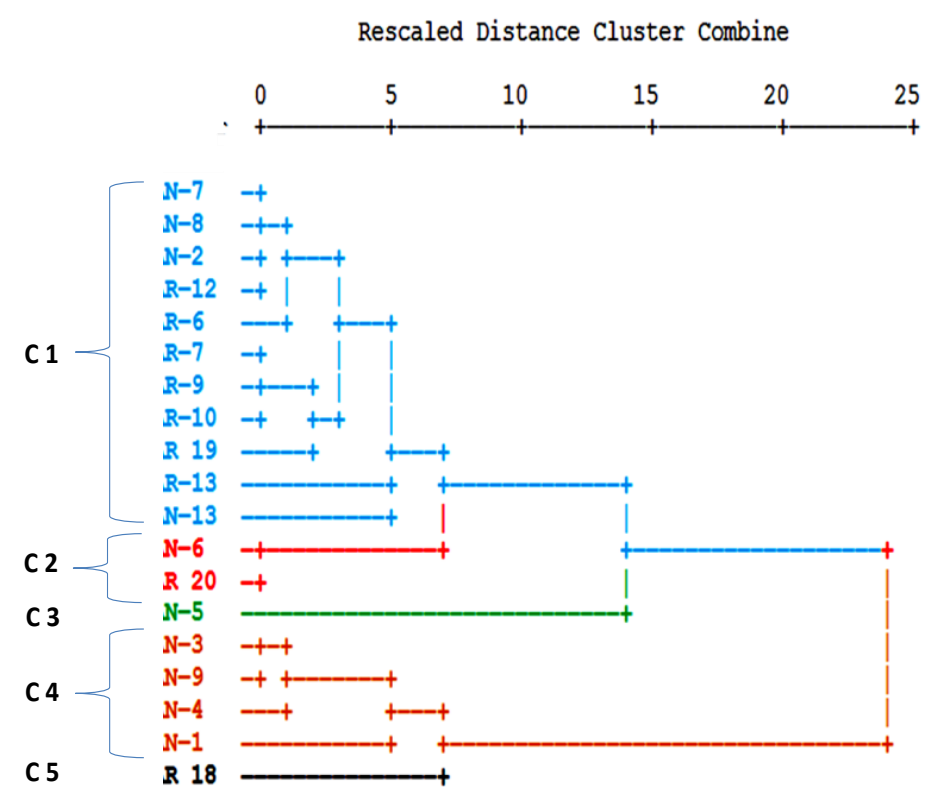

Figure 7. Dendrogram of a cluster analysis in Q-mode with the separation of five clusters (C1-C5) at a fusion value of six.

As the dendrogram indicates, two different groups can be clearly separated at a fusion level of 15, formed by the clusters $\mathrm{C} 1, \mathrm{C} 2, \mathrm{C} 3$, which correspond to the eastern part of the study area, and the clusters $\mathrm{C} 4$ and $\mathrm{C} 5$, found in the central and western part (Figure 8).

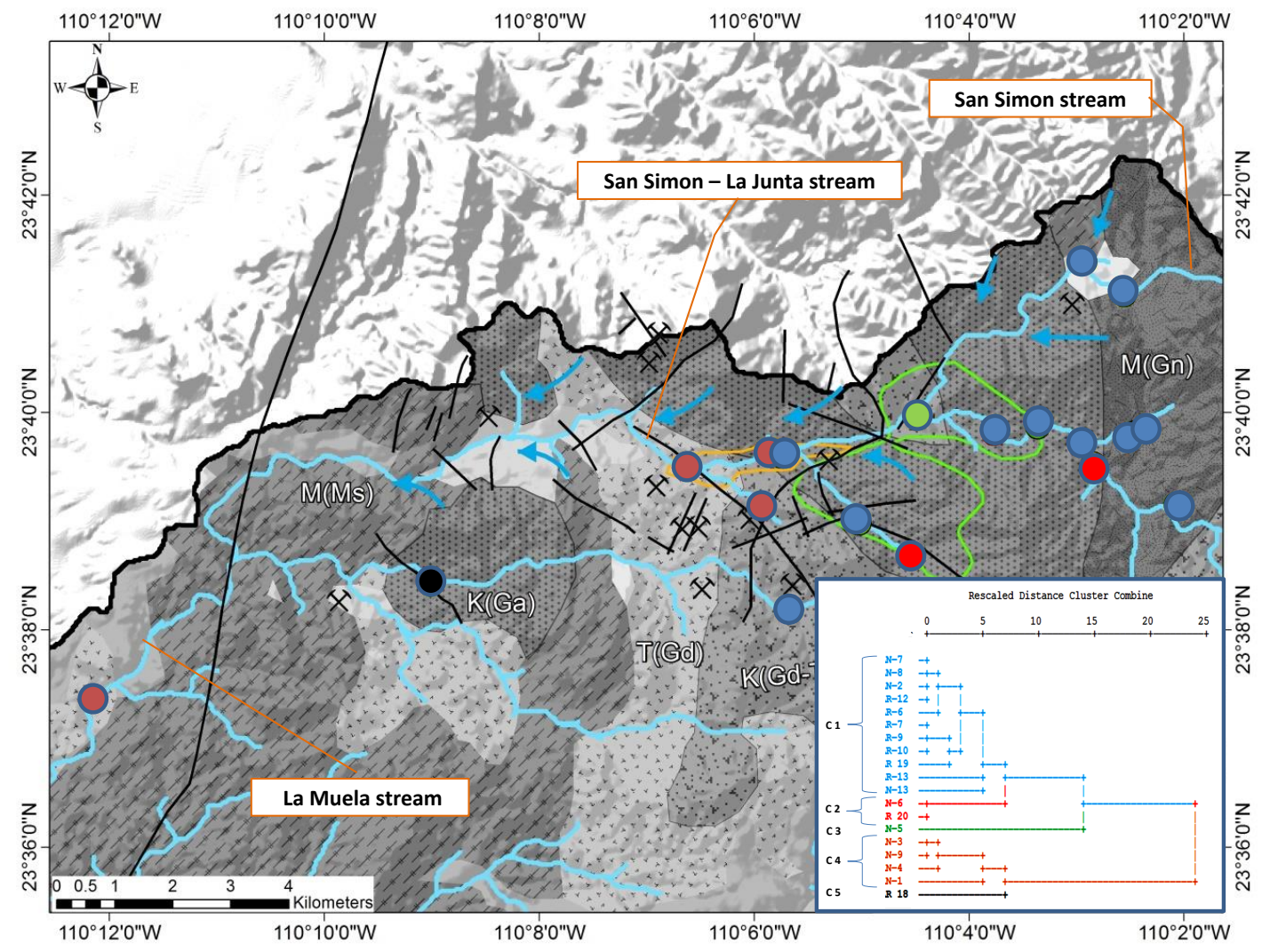

Figure 8. Dendrogram and map of the result of the cluster analysis in Q-mode with the separation of five clusters (C1-C5) at a fusion value of six. 
In the resulting dendrogram in R-mode, three different clusters were separated at a fusion value of five (see Figure 9).

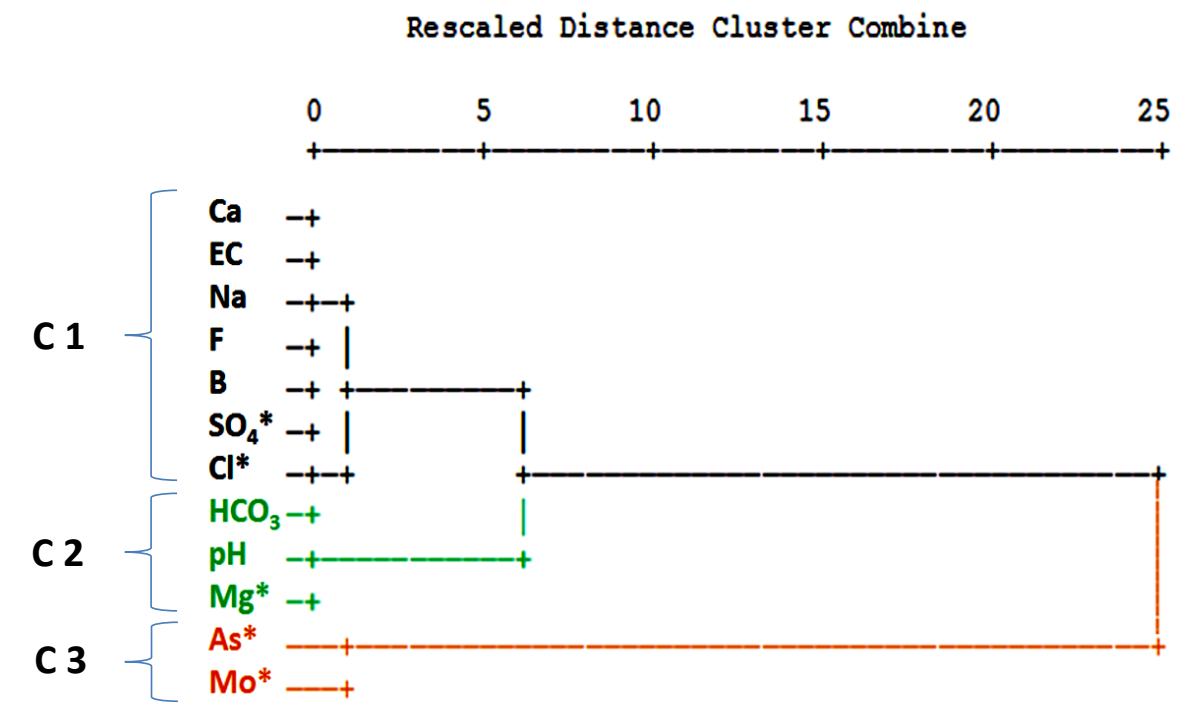

Figure 9. Dendrogram of a cluster analysis in R-mode with the separation of three clusters at a fusion value of five.

Three clusters were separated at a fusion value of five. Cluster 1 is formed by calcium, electrical conductivity, sodium, fluoride, boron, sulfate, and chloride and can be interpreted as influenced by mineralization in general with an increase towards the La Muela creek and boron, which represents the influx of thermal water. The second cluster (C2) includes bicarbonate, $\mathrm{pH}$ value, and magnesium. In a former study, a high correlation was found among $\mathrm{HCO}_{3}$ concentration and the distance of the station from ore-treating sites [45]. Low $\mathrm{Mg}$ concentrations and higher $\mathrm{pH}$ values are associated with mixtures of hydrothermal water [26]. Cluster 3 is formed by arsenic and molybdenum, elements which indicate the contamination at the former mining area and the zone of a gold and arsenopyrite anomaly. For the groundwater in the study area, Wurl et al. [26] found positive correlations (Pearson Correlation Coefficient at a significance level $(p)<0.01)$ among arsenic and sulfate of 0.607 and arsenic and molybdenum $(r=0.578)$, which was explained by a similar distribution of arsenopyrite and molybdenum in sulphide-rich ore zones. Romero et al. [46] identified arsenopyrite oxidation as the main As source at San Francisco tailings dump in Zimapán, Mexico.

\subsection{Temporal Variations}

The monthly monitoring at three stations in the arroyo La Junta started in May 2010 but after two sample campaigns, the stations S1 and S2 fell dry in July. From Mid-August to the end of September rainfall occurred for eight days, so that the sampling was continued at all three stations, and ended in January 2011. The precipitation accumulated to a total of $213 \mathrm{~mm}$ (registered at San Antonio weather station).

The concentrations of total suspended solids (Figure 10A) and the chemical demand of oxygen (Figure 10B) rose in station S2 during times of low streamflow, shortly before falling dry. During the rain events, the chemical demand of oxygen rises immediately meanwhile the peak concentration for total suspended solids was observed with a delay of about two months. 


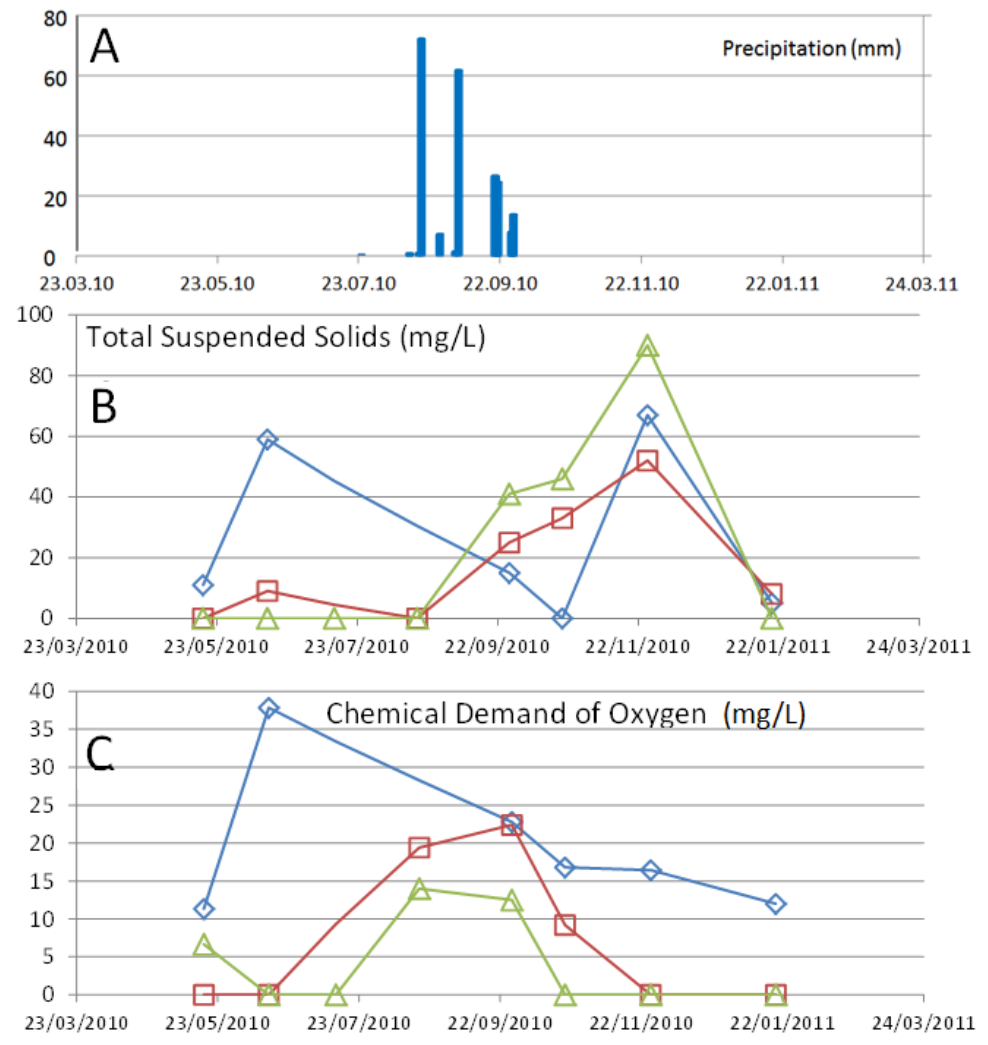

Figure 10. (A) The occurrence of several rain events between the 19 of August and the end of September, with total of $213 \mathrm{~mm}$ of precipitation (registered at San Antonio weather station). (B) The concentrations of total suspended solids and (C) the chemical demand of oxygen, observed at the three station in the La Junta arroyo S3 (upstream; green triangles), S1 (middle stream; red squares) and S2 (downstream; blue diamonds) in the month of October.

The mineralization (total dissolved solids) in the creek rises along the flow path (Figure 11). Precipitations led to reduced mineralization in the upper part of the sub-basin but higher mineralization in the lower part. The tendency of lower mineralization in the upper part of the arroyo La Junta and higher mineralization when reaching the La Muela arroyo persists during the nine month of observation at the stations S1 to S3. The concentrations of dissolved oxygen rose with the decrease of the temperature in autumn, due to the elevated solubility of oxygen.

The variation of total arsenic and sulfate do not coincide (Figure 12). Upstream (S3): Arsenic is fairly steady, no significant change is seen from before to after rain events while $\mathrm{SO}_{4}{ }^{2-}$ shows some increase before the rain events and again during the rain. 

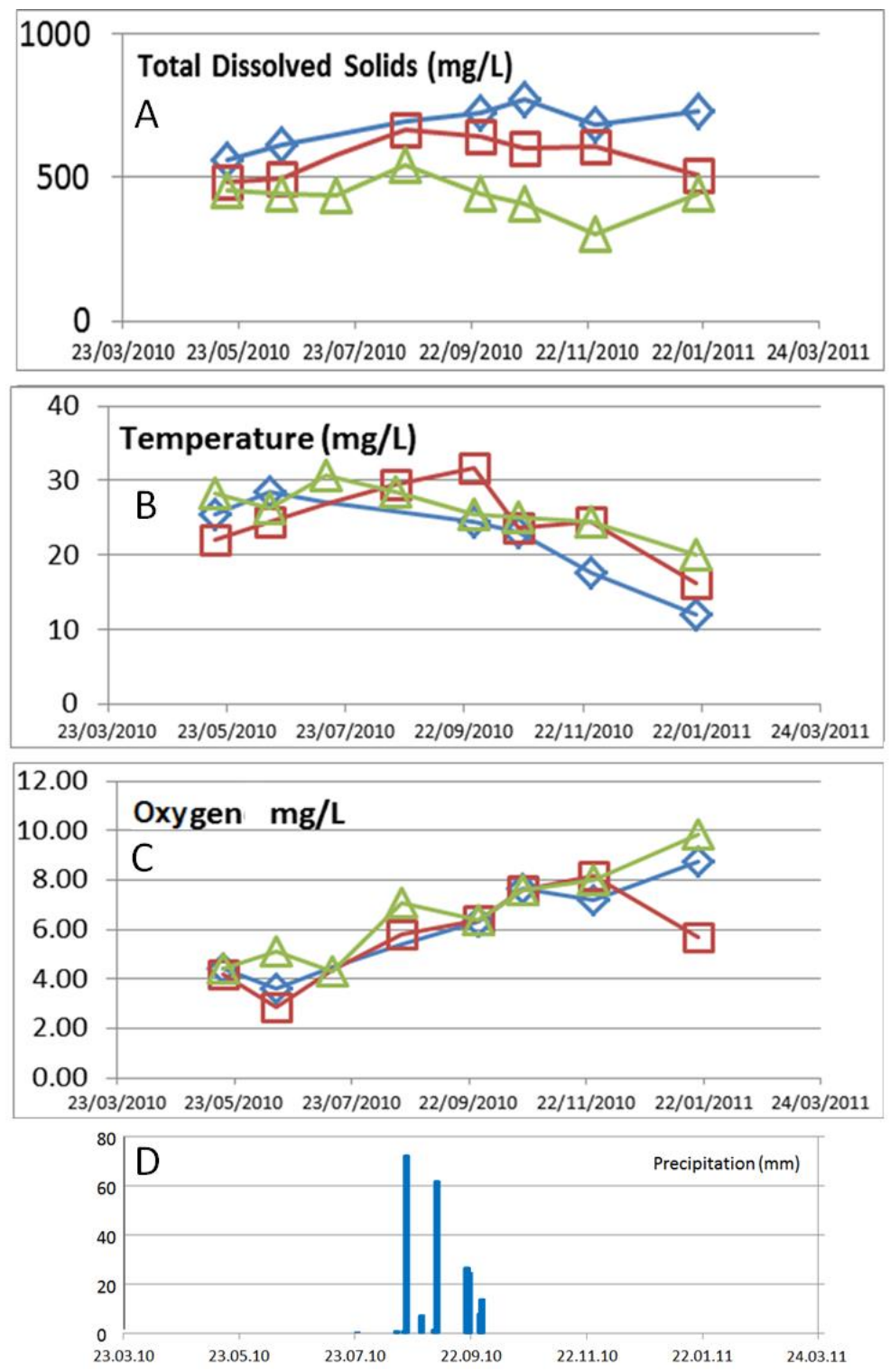

Figure 11. The concentrations of total dissolved solids (A) temperature (B) and dissolved oxygen (C), observed at the three station in the La Junta arroyo (upstream; green triangles), S1 (middle stream; red squares) and S2 (downstream; blue diamonds) in the month of October. (D) The occurrence of several rain events between the 19 of August and the end of September, with total of $213 \mathrm{~mm}$ of precipitation (registered at San Antonio weather station).

Midstream (S1): Arsenic and $\mathrm{SO}_{4}{ }^{2-}$ do increase together prior to the more intense rain and decrease after. This is entering into the mined area so, based on this congruous behavior, arsenopyrite were weathering here and releasing $\mathrm{As}$ and $\mathrm{SO}_{4}{ }^{2-}$.

Downstream (S2): Arsenic and $\mathrm{SO}_{4}{ }^{2-}$ have opposite behavior. There is a spike in As during drier times before the more intense rain and then, concentrations seem to equilibrate after the rain. Conversely, the spike in $\mathrm{SO}_{4}{ }^{2-}$ is after the rain. 

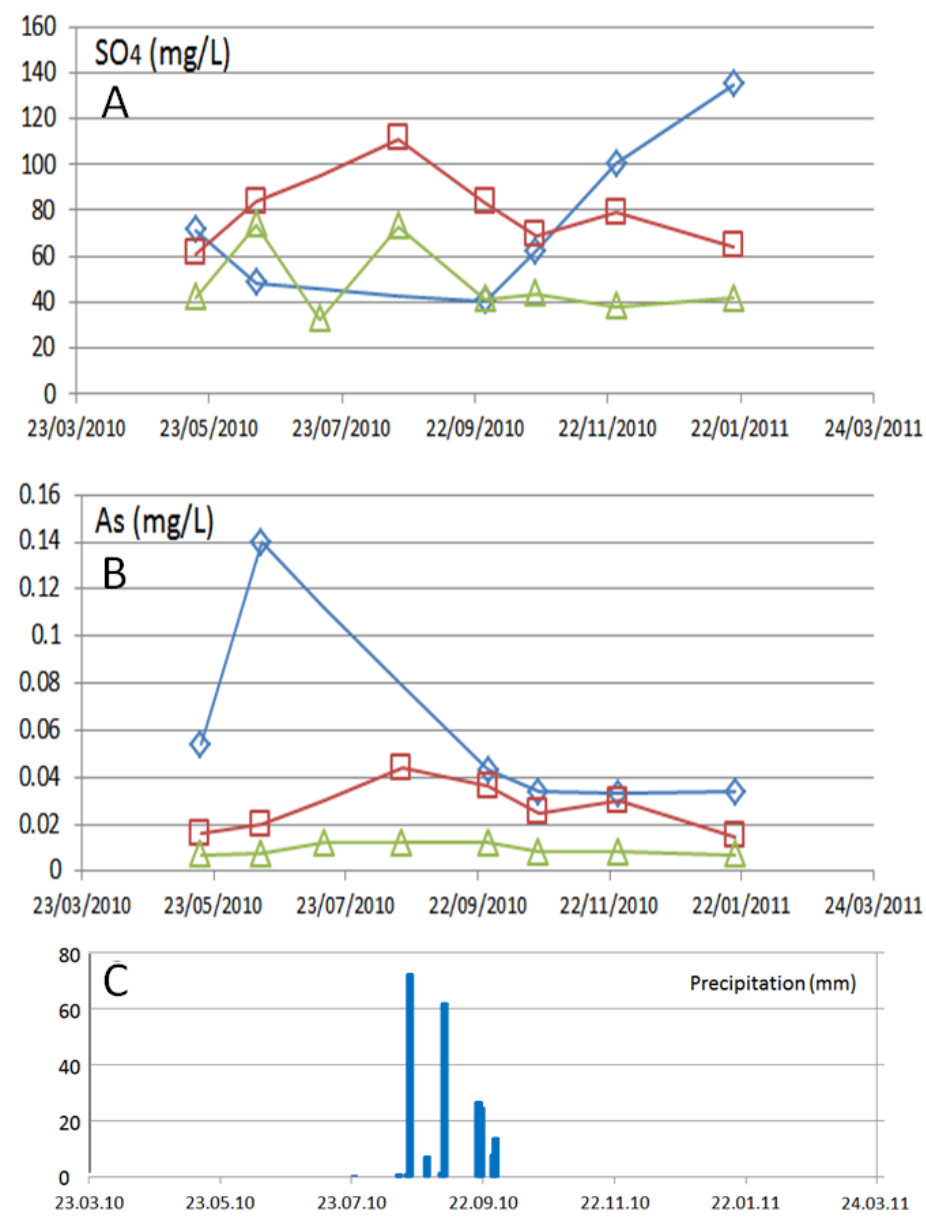

Figure 12. Concentrations of sulfate (A) and arsenic (B) in surface water at the three station in the La Junta arroyo S3 (upstream; green triangles), S1 (middle stream; red squares) and S2 (downstream; blue diamonds) in the month of October. (C) The occurrence of several rain events between the 19 of August and the end of September, with total of $213 \mathrm{~mm}$ of precipitation (registered at San Antonio weather station).

The boron concentrations were elevated after the rain events and the $\mathrm{pH}$ changed to more alkaline values, indicating more influence of thermal water. With more time there was a reduction of boron notable at all three stations, see Figure 13. 

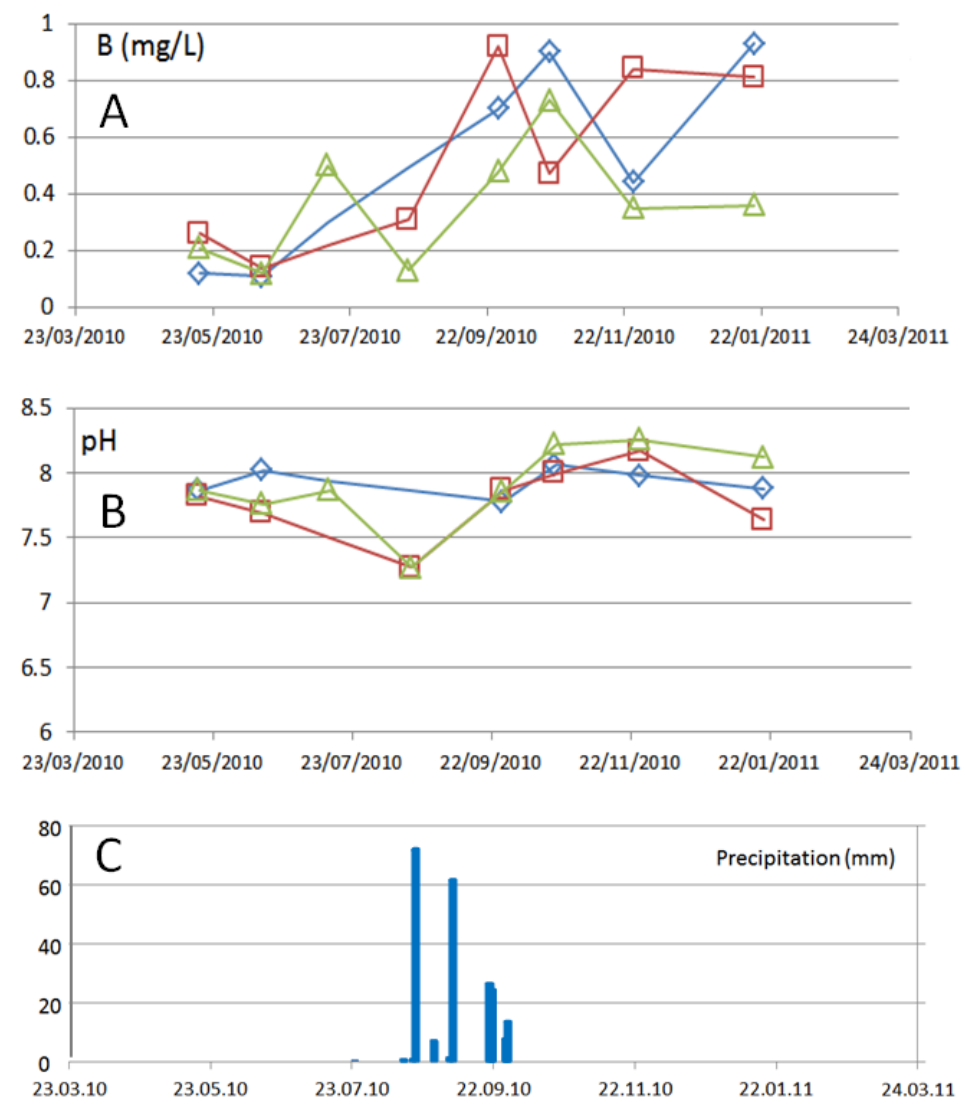

Figure 13. Variation of the boron concentrations (A) and $\mathrm{pH}$ values (B) in surface water at the three station in the La Junta arroyo S3 (upstream; green triangles), S1 (middle stream; red squares) and S2 (downstream; blue diamonds). (C) The occurrence of several rain events between the 19 of August and the end of September, with total of $213 \mathrm{~mm}$ of precipitation (registered at San Antonio weather station).

\section{Discussion}

The surface water shows elevated concentrations of As (Arsenic peaks greater than the WHO regulations and Mexican regulation standard for drinking water [43] indicates, especially in times off low runoff, when a high percentage of baseflow can be expected. This is a new observation, as in their study of the northern part of the mining district El Triunfo-San Antonio Carrillo-Chavez et al., (2000) [15] conclude that the arsenic concentrations vary especially after the heavy summer thunderstorms. Arsenopyrite represents the natural source mineral for arsenic in the study area [47], but there is only correlation among arsenic and sulfate at middle stream (S1), as temporal variations of both indicate. At the other stations, both parameters do not show similarities. Here soluble $\mathrm{SO}_{4}{ }^{2-}$ salts (e.g., gypsum, Fe sulfate) may form during dry times and then dissolve during precipitation events, releasing a flux of $\mathrm{SO}_{4}{ }^{2-}$. Downstream (S2) arsenolite $\left(\mathrm{As}_{2} \mathrm{O}_{3}\right)$, which was historically produced as a byproduct of gold and silver extraction in Southernmost Baja California Peninsula, is the main source of arsenic in the surface water. Arsenolite is found near the historic mines and processing facilities in the San Antonio-El Triunfo area, where more than 800,000 tons of mine waste material (with an average content of $4 \%$ arsenic oxide) were left behind [19]. This finding is supported by the cluster analysis, which revealed that the water composition in La Junta, before and after passing through the area of historic gold mining, varies substantially meanwhile the mineralized zone with arsenopyrite does not provoke important changes to the water composition.

The mineralization of the surface water in the arroyo La Junta rises along the flow path. Although the metamorphic rocks only permit water circulation via fractures, piezometric water levels indicate a general groundwater flow into the arroyo La Junta, which drains the area [26]). The hydraulic 
connection between groundwater and surface water can be recognized by the changes of the surface water composition, after passing through areas of elevated arsenic concentrations in the groundwater.

The maximum concentrations for arsenic in the La Junta arroyo were lower than reported for the northern parts of the mining district. This is also congruent to the lower arsenics concentrations in the groundwater of the study area [26]. One reason is that the ore processing facilities (causing today the highest contamination) were located in the northern part of the mining district. In addition, the longer time span between the last mining activities and the sampling campaign in the area of La Junta represents also important factor: Naranjo-Pulido et al. [48] observed a lower average arsenic concentration (in the bioavailable fraction) of the soils from the historic mine pits in El Triunfo $(8.68 \mathrm{mg} / \mathrm{kg})$ than in the adjacent San Antonio area $(12.46 \mathrm{mg} / \mathrm{kg})$, which they attributed to a more recent mining activity here. Naranjo-Pulido et al. (2002) [48] see precipitation and the wind as other factors that determine the arsenic distribution in the soil. Carillo and Huyck (1997) [47] concluded that especially wind plays an important role for dispersion of the arsenic in the area, which is supported by Volke-Sepúlveda et al. (2003) [16], who detected elevated concentrations in respect to As (maximum $>20,000 \mathrm{mg} / \mathrm{kg}$ ), Cd (maximum $>300 \mathrm{mg} / \mathrm{kg}$ ), $\mathrm{Pb}$ (maximum $>120,000 \mathrm{mg} / \mathrm{kg}$ ), and $\mathrm{Zn}$ in ashes and waste piles. Even in the natural soils of the Mining District, concentrations are often above the Mexican regulation standard for soils [16].

The temporal variation of the surface water composition shows that elevated concentrations for arsenic are related to longer times after rain events when runoff depends mainly on the baseflow. This is in congruence to Carrillo-Chávez et al. [15], who found significant variations of As levels in groundwater before, during, and after the rainy season. Rain contributes to arsenic lixiviation and mobilization, increasing As levels in groundwater, especially near ore treatment sites [15] and therefore appears to be the determinant factor of As distribution. The concentrations of some typical byproducts in the surface water reported from many other gold mining areas were not elevated in case of La Junta, with respect to the drinking water standards [25]. In lixiviation test on ten core samples from diorite in the center of the study area with a natural anomaly, applied after the Mexican regulation NOM-053-SEMARNAT-1993 [49] (which coincides with the U.S. Code of Federal Regulations, Vol. 40, Part 260, 1991) indicated no significant metal leaching. Concentration for As, Ba, Cd, Cr, Hg, Ag, Se were under the quantification limit and in the case of $\mathrm{Pb}$, only two samples showed concentrations above the limit $(0.47 \mathrm{mg} / \mathrm{kg}$ and $0.28 \mathrm{mg} / \mathrm{kg}$ [50]). Even mercury, which was used in the ore processing, did not show elevated concentrations (above calibration limit). In contrast, Volke-Sepúlveda et al. [16], who conducted lixiviation test to analyze the contaminant bioavailability from tailings and ashes, found that the elements $\mathrm{Ni}, \mathrm{Sb}, \mathrm{Cd}, \mathrm{Ba}, \mathrm{Cu}, \mathrm{As}, \mathrm{Pb}$ and $\mathrm{Zn}$ could be dissolved in significant concentrations (maximum values in ascendant order from $0.58 \mathrm{mg} / \mathrm{L}$ to $71.06 \mathrm{mg} / \mathrm{L}$ ) while $\mathrm{CN}^{-}, \mathrm{Hg}, \mathrm{Cr}, \mathrm{Co}$, and $\mathrm{Ag}$ reached only minor concentrations.

As our study indicates, in congruence with results for the rest of the mining district and nearby areas, the population is exposed to elevated concentrations of arsenic in the surface- and groundwater. Arsenic is soluble over a wide range of $\mathrm{pH}$ and Eh conditions and exists in natural water mainly in the trivalent $\left(\mathrm{As}^{3+}\right)$, and pentavalent $\left(\mathrm{As}^{5+}\right)$ valency state [51,52]). In the surface water, under the oxidizing environmental conditions, the pentavalent species of arsenic are predominant; only one sample showed reducing environmental conditions with predominance of the $\left(\mathrm{As}^{3+}\right)$ species. The trivalent compounds of arsenic are generally more toxic than pentavalent compounds [53-56]). Although the observed arsenic concentrations in the surface water are lower than the concentrations of arsenic, reported for the groundwater of the same area [26], a negative impact may result because even low levels of As may be carcinogenic. A cancer risk of 1 in 1000 persons, in case of ingesting drinking water containing $2.5 \mathrm{\mu g} / \mathrm{L}$ of total As and a consumption of $1.6 \mathrm{~L}$ per day, has been described; at a level of $50 \mu \mathrm{g} / \mathrm{L}$ of total As and a consumption of $1.6 \mathrm{~L}$ per day the cancer risk rises up to 21 times $[57,58]$. The level of contamination in the population in and near the mining district has been investigated by Colín-Torres et al. (2014) [59], who analyzed the urine of 275 adult inhabitants (66\% female, $34 \%$ male; representing $4.8 \%$ of the total population in the area) from seven villages, located in the Los Planes and 
El Carrizal watersheds. The urinary samples contained a total arsenic concentration (sum of arsenical species) which ranged from 1.3 to $398.7 \mu \mathrm{g} / \mathrm{L}$. One third of the inhabitants surpassed the biological exposition index (BEI) of $35 \mu \mathrm{g} / \mathrm{L}$. This index defines the permissible limit for occupational exposure to arsenic.

\section{Conclusions}

The aim of this detailed environmental study was to investigate contamination sources and dispersal resulting from historical mining practices and to distinguish between natural and mining sources of metals/metalloids with a specific focus on the surface water. We investigated the La Junta creek, in the southern part of the mining district San Antonio-El Triunfo by means of a spatial analysis of surface water and shallow groundwater in combination with the temporal observation of the concentrations in runoff water. The effects of different sources of arsenic (natural geogene anomalies, contamination due to historic mining activity and hydrothermal related impact in the La Junta creek were recognized. In the surface water of the study area historic mining activity caused major impact of arsenic than the naturally mineralized zone (anomaly of gold, silver, and byproducts like arsenic), but compared to the situation in the northern part of the mining district, less As contamination was observed. The elevated arsenic concentrations in stream water generally occurred during times of low streamflow. This water quality assessment is essential for future implementation of monitoring and remediation programs, in order to minimize adverse impacts on human health and the aquatic ecosystem.

Supplementary Materials: The following are available online at http://www.mdpi.com/1660-4601/15/3/ 437/s1. The results of 19 samples taken in October, (total and dissolved element concentrations including the charge balance error), are documented in the Table S1: Stations and the Table S2: Temporal Variations (May 2010-January 2011).

Acknowledgments: The article was elaborated, based partly on surface water analyses documented in the report: Wurl, J.; Méndez-Rodríguez, L.; Acosta-Vargas, B.; Loa-Malagón, J.; Rochin Banaga, H. Estudio de los aspectos edafológicos, geotécnicos e hidrológicos del proyecto minero metalúrgico Paredones Amarillos, B.C.S., México, Parte c, aspectos hidrológicos, geohidrológicos y hidrogeoquímicos, prepared for Minera Concordia. S.A. de C.V. by Universidad Autonoma de Baja California Sur, 2011. (in Spanish) contracted by the Concordia Project Mining Company. We thank the Concordia Project for the permission to publish the data and also SEMARNAT-CONACyT 249423.

Author Contributions: Jobst Wurl and Lía Mendez-Rodriguez designed the study and all authors contributed to the field work; Jobst Wurl and Miguel Imaz Lamadrid analyzed the data and wrote the paper.

Conflicts of Interest: The authors declare no conflict of interest.

\section{References}

1. Cassassuce, F.; Olvera, J.; Loera-Pizarro, E. Estudio de la Calidad del Agua en 500 Pozos de Baja California Sur; Sociedad de Historia Natural Niparajá, A.C. en Colaboración con la CONAGUA: La Paz, Mexico, 2005; 27p. (In Spanish)

2. Gutiérrez Caminero, L. Lead Isotopes as Tracers for Metal and Metalloid Sources in the San Antonio-El Triunfo Mining District, Baja California Sur. Master's Thesis, CICESE, November 2013. Available online: https://cicese.repositorioinstitucional.mx/jspui/bitstream/1007/919/1/233611.pdf (accessed on 11 December 2017).

3. Instituto Nacional de Estadística, Geografía e Informática, INEGI. Carta Topográfica 1:50,000, El Rosario F12B23. In stituto Nacional de Estadística, Geografía e Informática; INEGI City, México, 2002. Available online: http:/ /internet.contenidos.inegi.org.mx/contenidos/Productos/prod_serv/contenidos / espanol/bvinegi/productos/geografia/imagen_cartografica/1_50_000/702825701604.pdf (accessed on 11 December 2017). (In Spanish) 
4. Vanderplank, S.; Wilder, B.T.; Ezcurra, E. Arroyo la Junta: Una Joya de Biodiversidad en la Reserva de la Biosfera Sierra la Laguna/a Biodiversity Jewel in the Sierra la Laguna Biosphere Reserve. Botanical Research Institute of Texas, Next Generation Sonoran Desert Researchers, and UC MEXUS, 2016. Available online: http:/ / nextgensd.com/wp-content/uploads/2016/06/Los-Cardones_digital.pdf (accessed on 11 Decmber 2017). (In Spanish)

5. Norma Oficial Mexicana NOM-059-SEMARNAT-2001, Protección Ambiental-Especies Nativas de México de Flora y Fauna Silvestres-Categorías de Riesgo y Especificaciones para su Inclusión, Exclusión o Cambio-Lista de Especies en en Riesgo. 2001. Available online: http:/ / www.biodiversidad.gob.mx/pdf/NOM-059-ECOL2001.pdf (accessed on 11 December 2017). (In Spanish)

6. Servicio Meteorológico Nacional SMN. Base de Datos de Precipitaciones, Evaporación y Temperaturas Diarias de la Estación Climatológica 3049 San Antonio. Available online: http:/ / smn.cna.gob.mx/tools / RESOURCES/Normales8110/NORMAL03049.TXT (accessed on 5 August 2017). (In Spanish)

7. Wurl, J.; Martínez Gutiérrez, G. El efecto de ciclones tropicales sobre el clima en la cuenca de Santiago, Baja California Sur, México. In Proceedings of the III Simposio Internacional en Ingeniería y Ciencias para la Sustentabilidad Ambiental y Semana del Ambiente, Santiago de Compostela, Mexico, 5-6 June 2006. (In Spanish)

8. Cuevas Limón, L.F. Estudio Geohidrológico-Geofísico Realizado en la Región del Proyecto Minero "Paredones Amarillos", Cuenca del Arroyo San Simón La Muela; Municipio de La Paz, B.C.S.: La Paz, Mexico, 1996. (In Spanish)

9. Arriaga, L.; León de la Luz, J.L. The Mexican tropical deciduous forest of Baja California Sur: A floristic and structural approach. Vegetatio 1989, 84, 45-52. [CrossRef]

10. Aranda-Gómez, J.J.; Pérez-Venzor, J.A. Estratigrafía del Complejo Cristalino de la región de Todos Santos, Estado de Baja California Sur. Revista 1989, 8, 149-170. (In Spanish)

11. Fletcher, J.M.; Kohn, B.P.; Foster, D.A.; Gleadow, A.J.W. Heterogeneous Neogene cooling and exhumation of the Los Cabos block, southern Baja California: Evidence from fission-track thermochronology. Geology 2000, 28, 107-110. [CrossRef]

12. Koutz, F.R. 1994-1995 Annual Report: Surficial Geologic Work, Greater Paredones Project Internal Echo Bay Draft Report; La Paz Municipality: Baja California Sur, México, 1995; 33p.

13. Bay, E. Exploration Mexico: Paredones Amarillos Project Level II Feasibility Study Board of Directors Briefing Document. 1996. (In Spanish)

14. CAM (Corporación Ambiental de México S.A. de C.V.). Manifestación de Impacto Ambiental Modalidad Particular, Proyecto de Exploración Minera Paredones Amarillos, Municipio de La Paz B.C.S. In Paredones Amarillos S.A. de C.V.; La Paz B.C.S. Proyecto CAM 07023; 2007; 136p. Available online: http:/ / sinat.semarnat. gob.mx/dgiraDocs/documentos/bcs/resumenes/2007/03BS2007M0013.pdf (accessed on 11 December 2017). (In Spanish)

15. Carrillo-Chávez, A.; Drever, J.I.; Martínez, M. Arsenic content and groundwater geochemistry of the San Antonio-El Triunfo, Carrizal and Los Planes aquifers in Southernmost Baja California, Mexico. Environ. Geol. 2000, 39, 1295-1303. [CrossRef]

16. Volke-Sepúlveda, T.; Solórzano-Ochoa, G.; Rosas-Domínguez, A.; Izumikawa, I.; Encarnación-Aguilar, G.; Velasco-Trejo, J.A.; Flores Martínez, S. Informe Final, Remediacion de Sitios Contaminados por Metales Provenientes de jales Mineros en los Distritos de El Triunfo-San Antonio y Santa Rosalía, Baja California Sur, Mexico. 2003; 37p. Available online: http:/ / www2.ine.gob.mx/dgcenica/descargas/remediacion2003.pdf (accessed on 11 December 2014). (In Spanish)

17. Carrillo, A. Environmental Geochemistry of the San Antonio-El Triunfo Mining Area, Baja California Peninsula, Mexico. Ph.D. Thesis, University of Wyoming, Laramie, WY, USA, May 1996. Available online: http:/ / defiendelasierra.org/wp-content/uploads/2015/09/Carrillo-1996_Wyoming.pdf (accessed on 11 December 2017).

18. Romero-Guadarrama, J.A. Geoquímica de $\mathrm{As}, \mathrm{Hg}, \mathrm{Pb}$ y $\mathrm{Zn}$ y Mineralogía en Sedimentos Superficiales de la Cuenca de Drenaje del Distrito Minero El Triunfo, BCS, México. Master's Thesis, CICIMAR-IPN, Mexico, 2011. Available online: www.repositoriodigital.ipn.mx/bitstream/123456789/14758/1/Tesis-final. pdf (accessed on 11 December 2014). (In Spanish)

19. Carrillo, A.; Drever, J. Environmental assessment of the potential for arsenic leaching into groundwater from mine wastes in Baja California Sur, México. Geofís. Int. 1998, 37, 35-39. 
20. SGM (Servicio Geologico Mexicano). Carta Geologica-Minera 1:250,000, El Rosario F12-B23. In Secretaria de Economia; La Paz, Baja California Sur, Mexico, 2000. Available online: http:/ / mapserver.sgm.gob.mx/ Cartas_Online/geologia/374_F12-B23_GM.pdf (accessed on 11 December 2017). (In Spanish)

21. Posada-Ayala, I.H. Geoquímica Ambiental del Distrito Minero San Antonio, Sedimentos de los Streams de la Cuenca de San Juan de Los Planes y Plataforma Continental de Bahía La Ventana, BCS, México. Master's Thesis, CICIMAR-IPN, 2011. Available online: http://tesis.ipn.mx/handle/123456789/19165 (accessed on 11 December 2014). (In Spanish)

22. Sánchez-Martínez, M.A.; Marmolejo-Rodríguez, A.J.; Gómez Millán, R.; Sánchez-González, A.; Magallanes-Ordoñez, V.R.; Romero-Guadarrama, J.A. Sediment accumulation of Ag, Cu, and Ni through a semi-arid basin as a by-product of the El Triunfo gold mine, Baja California Sur Mexico. J. Iber. Geol. 2013, 39, 97-110. [CrossRef]

23. Sobrino-Figueroa, A.S.; Becerra-Rueda, O.F.; Magañanes-Ordoñez, V.R.; Sánchez-González, A.; Marmolejo-Rodríguez, A.J. Toxicity in semiarid sediments influenced by tailings of an abandoned gold mine. Environ. Monit. Assess. 2015, 187, 41-58. [CrossRef] [PubMed]

24. Marmolejo-Rodríguez, A.J.; Sánchez-Martínez, M.A.; Romero-Guadarrama, J.A.; Sánchez-González, A.; Magallanes-Ordóñez, V.R. Migration of $\mathrm{As}, \mathrm{Hg}, \mathrm{Pb}$, and $\mathrm{Zn}$ in arroyo sediments from a semiarid coastal system influenced by the abandoned gold mining district at El Triunfo, Baja California Sur, Mexico. J. Environ. Monit. 2011, 13, 2182-2189. [CrossRef] [PubMed]

25. World Health Organization (WHO). Guidelines for Drinking-Water Quality. Health Criteria and Other Supporting Information, 4th ed.; WHO: Geneva, Switzerland, 2011; p. 564.

26. Wurl, J.; Mendez-Rodriguez, L.; Acosta-Vargas, B. Arsenic content in groundwater from the southern part of the San Antonio-El Triunfo mining district, Baja California Sur, Mexico. J. Hydrol. 2014, 518, 447-459. [CrossRef]

27. Wedepohl, K.H. The continental crust. Geochim. Cosmochim. Acta 1995, 59, 1217-1232. [CrossRef]

28. American Public Health Association, APHA. Standard Methods for the Examination of Water and Wastewater; APHA: Washington, DC, USA, 1992.

29. Norma Mexicana. NMX-AA-008-SCFI-2000. Que Establece la Metodología para la Determinación del pH en Aguas Residuales. Secretaría de Comercio y Fomento Industrial: México, 2000. Available online: https: / /agua.org.mx/wp-content/uploads/2011/01/nmx-aa-008-scfi-2000.pdf (accessed on 11 December 2017). (In Spanish)

30. Norma Mexicana NMX-AA-093-SCFI-2000. Análisis de Agua. Determinación de la Conductividad Electrolítica. Método de Prueba. Secretaría de Comercio y Fomento Industrial CDU.631.879.27. Available online: http://lasa.ciga.unam.mx/monitoreo/images/biblioteca/46\%20NMX-AA-093-SCFI2000_Conductividad.pdf (accessed on 11 December 2017). (In Spanish)

31. Norma Mexicana NMX-AA-036-SCFI-2001. Análisis de Agua, Determinación de acidez y Alcalinidad en Aguas Naturales, Residuales y Residuales Tratadas-Método de Prueba. 2001. Available online: https:/ / www.gob.mx/cms/uploads/attachment/ file/166776/NMX-AA-036-SCFI-2001.pdf (accessed on 11 December 2017). (In Spanish)

32. Norma Mexicana NMX (2001a) Norma Mexicana NMX-AA-073-SCFI-2001. Análisis de agua-Determinación de Cloruros Totales en Aguas Naturales, Residuales, y Residuales Tratadas-Método de Prueba. Secretaría de Economía. 2001. Available online: https://agua.org.mx/biblioteca/nmx-aa-073-scfi-2001-analisis-deagua-determinacion-de-cloruros-totales-en-aguas-naturales-residuales-y-residuales-tratadas-metodo-deprueba / (accessed on 11 December 2017). (In Spanish)

33. Norma Mexicana NMX-AA-077-SCFI-2001. "Análisis de Aguas; Determinación de Fluoruros en Aguas Naturales, Residuales y Residuales Tratadas". In Diario Oficial de la Nación; 2001; (Cancela a NMX-AA-077-1982). Available online: http://biblioteca.semarnat.gob.mx/janium/Documentos/Ciga/ agenda/PPD1/DO86.pdf (accessed on 11 December 2017). (In Spanish)

34. Norma Mexicana NMX-AA-074-SCFI-1981. Water Analysis. Determination of Sulfate Ion in Natural Waters, Wastewaters and Treated Waters. In Secretaría de Economía; 1981. Available online: https://www.gob. $\mathrm{mx} / \mathrm{cms} /$ uploads/attachment/file/166149/nmx-aa-074-scfi-2014.pdf (accessed on 11 December 2017). (In Spanish) 
35. Edgell, K. USEPA Method Study 37 SW-846 Method 3050 acid Digestion of Sediments, Sludges, and Soils. 1989; US Environmental Protection Agency, Environmental Monitoring Systems Laboratory. Available online: https: / nepis.epa.gov/Exe/ZyPURL.cgi?Dockey=2000TTR9.TXT (accessed on 11 December 2017).

36. Norma Mexicana NMX-AA-051-SCFI-1981. Determinación de Metales, Método Espectrofotométrico de Absorción Atómica. 1982. Available online: https:/ /www.gob.mx/cms/uploads/attachment/file/166785/ NMX-AA-051-SCFI-2001.pdf (accessed on 11 December 2017). (In Spanish)

37. NMX-AA-063-SCFI-2001, Análisis de Agua. Determinación de Boro en Aguas Naturales, Residuales y Residuales Tratadas. Método de Prueba. 2001. Available online: http://www.gob.mx/cms/uploads/ attachment/ file/166786/NMX-AA-063-SCFI-2001.pdf (accessed on 11 December 2017). (In Spanish)

38. NMX-AA-058-SCFI-2001. Análisis de Aguas-Determinación de Cianuros Totales en Aguas na-Turales, Potables, Residuales y Residuales Trata-Das-Método de Prueba. 2001; pp. 1-23. Available online: https:/ / www.gob.mx/cms/uploads/attachment/file/166784/NMX-AA-058-SCFI-2001.pdf (accessed on 11 December 2017). (In Spanish)

39. DVWK-Regeln Zur Wasserwirtschaft H. Entnahme und Untersuchungsumfang von Grundwasserproben. In DK 556.32.001.5 Grundwasseruntersuchung, DK 543.3.053 Probenahme. DVWK-Regeln zur Wasserwirtschaft 128, 36; Deutscher Verband für Wasserwirtschaft und Kulturbau e. V.: Hamburg/Berlin, Germany, 1992. (In German)

40. Carrillo, A.; Drever, J.I. Adsorption of arsenic by natural aquifer material in the San Antonio-El Triunfo mining area, Baja California. Environ. Geol. 1998, 35, 251-257. [CrossRef]

41. Magdaleno Rico, C.A. Peligrosidad de Los Residuos Mineros Históricos del Distrito Minero San Antonio-El Triunfo en La Paz Baja California Sur y Evaluación de Generación de Drenaje Ácido a Través de Pruebas Estáticas, Tesis de Licenciatura, Universidad Nacional Autónoma de México UNAM, FACULTAD DE INGENIERÍA). Available online: www.ptolomeo.unam.mx:8080/xmlui/bitstream/handle/132.248.52.100/ 3026/Tesis.pdf (accessed on 10 February 2014). (In Spanish)

42. Takeno, N. Atlas of Eh-pH Diagrams, Intercomparison of Thermodynamic Databases; File Report No. 419; National Institute of Advanced Industrial Science and Technology: Tokyo, Japan, 2005.

43. NOM-127-SSA1-1994 Modificacion a la Norma Oficial Mexicana NOM-127-SSA1-1994, Salud Ambiental. Agua para uso y Consumo Humano. Limites Permisibles de Calidad y Tratamientos a que debe Someterse el Agua Para su Potabilizacion. 2000; Mexico. Available online: http:/ /www.salud.gob.mx/unidades/cdi/ nom/m127ssa14.html (accessed on 11 December 2017). (In Spanish)

44. Bale, C.W.; Chartrand, P.; Degterov, S.A.; Eriksson, G.; Hack, K.; Mahfoud, R.B.; Melançon, J.; Pelton, A.D.; Petersen, S. FactSage Thermochemical Software and Databases. Calphad 2002, 26, 189. [CrossRef]

45. Méndez-Rodríguez, L.; Zenteno-Savín, T.; Acosta-Vargas, B.; Wurl, J.; Imaz-Lamadrid, M. Differences in arsenic, molybdenum, barium, and other physicochemical relationships in groundwater between sites with and without mining activities. Nat. Sci. 2013, 5, 238-243. [CrossRef]

46. Romero, F.M.; Armienta, M.A.; Villaseñor, G.; González, J.L. Mineralogical constraints on the mobility of arsenic in tailings from Zimapán, Hidalgo, Mexico. Int. J. Environ. Pollut. 2006, 26, 23-40. [CrossRef]

47. Carrillo, A.; Huyck, H. A genetic model for the Los Uvares gold deposit, Baja California Sur, Mexico. Geofis. Int. 1997, 36, 111-119.

48. Naranjo-Pulido, A.; Romero-Schmidt, H.; Mendez-Rodriguez, L.; Acosta-Vargas, B.; Ortega-Rubio, A. Soil arsenic contamination in the Cape Region, B.C.S. Mexico. J. Environ. Biol. 2002, 23, 347-352. [PubMed]

49. Norma Oficial Mexicana Nom-053-Semarnat-1993 Que Establece El Procedimiento Para Llevar a Cabo la Prueba De Extracción Para Determinar Los Constituyentes Que Hacen a un Residuo Peligroso por Su Toxicidad al Ambiente. Available online: http:/ /www.imss.gob.mx/sites/all/statics/profesionalesSalud/ investigacionSalud/cbis/nom-053-semarnat-1993.pdf (accessed on 11 December 2017). (In Spanish)

50. ONSITE Laboratories. Analysis to Determine the Characteristics of Corrosivity, Reactivity, Flammability and Toxicity to the Environment According to the Procedures and Sanctions in the Mexican Standard NOM-052-SEMARNAT-2005 Conducted on 10 Core Samples; ONSITE Laboratories: Bendigo, Australia, 2012; 100p.

51. Feng, Z.; Xia, Y.; Tian, D.; Wu, K.; Schmitt, M.; Kwok, R.K.; Mumford, J.L. DNA damage in buccal epithelial cells from individuals chronically exposed to arsenic via drinking water in Inner Mongolia, China. Anticancer Res. 2001, 21, 51-58. [PubMed]

52. Bell, F.G. Environmental Geology: Principles and Practice; Blackwell Science: London, UK, 1998; pp. 487-500. 
53. Smedley, P.L.; Kinniburgh, D.G. A review of the source, behavior and distribution of arsenic in natural waters. Appl. Geochem. 2002, 17, 517-568. [CrossRef]

54. Cervantes, C.; Ji, G.; Ramírez, J.L.; Silver, S. Resistance to arsenic compounds in microorganisms. FEMS Microbiol. Rev. 1994, 15, 355-367. [CrossRef] [PubMed]

55. Gao, S.; Burau, R.G. Environmental factors affecting rates of arsine evolution from and mineralization of arsenicals in soil. J. Environ. Qual. 1997, 26, 753-763. [CrossRef]

56. Cheng, C.N.; Focht, D.D. Production of arsine and methylarsines in soil and culture. Appl. Environ. Microbiol. 1979, 38, 494-498. [PubMed]

57. Smith, A.H.; Hopenhayn-Rich, C.; Bates, M.N.; Goeden, H.M.; Hertz-Picciotto, I.; Duggan, H.M.; Wood, R.; Kosnett, M.J.; Smith, M.T. Cancer risks from arsenic in drinking water. Environ. Health Perspect. 1992, 97, 259-267. [CrossRef] [PubMed]

58. Celik, I.; Gallicchio, L.; Boyd, K.; Lam, T.K.; Matanoski, G.; Tao, X.; Alberg, A.J. Arsenic in drinking water and lung cancer: A systematic review. Environ. Res. 2008, 108, 48-55. [CrossRef] [PubMed]

59. Colín-Torres, C.G.; Murillo-Jiménez, J.M.; Del Razo, L.M.; Sánchez-Peña, L.C.; Becerra-Rueda, O.F.; Marmolejo-Rodríguez, A.J. Urinary arsenic levels influenced by abandoned mine tailings in the Southernmost Baja California Peninsula, Mexico. Environ. Geochem. Health 2014, 36, 845-854. [CrossRef] [PubMed]

(C) 2018 by the authors. Licensee MDPI, Basel, Switzerland. This article is an open access article distributed under the terms and conditions of the Creative Commons Attribution (CC BY) license (http:/ / creativecommons.org/licenses/by/4.0/). 